\title{
Evaluation of Flowering Pattern, Yield and Yield Determinants of Hybrid Tea Rose in Response to Seasonal Variations and Applied Organic Manure Rates
}

\author{
Olusegun Olufemi Olubode, Sola Uthman Adekola, Sukurat Modupe Idowu \\ Federal University of Agriculture, Abeokuta, Nigeria \\ Email: bodefemyup02@gmail.com, olubodeoo@funaab.edu.ng
}

Received 13 December 2014; accepted 25 February 2015; published 27 February 2015

Copyright (C) 2015 by authors and Scientific Research Publishing Inc.

This work is licensed under the Creative Commons Attribution International License (CC BY). http://creativecommons.org/licenses/by/4.0/

(c) (i) Open Access

\section{Abstract}

Seasonal variations in environmental conditions can have significant influence on flowering pattern and yield of roses. Evaluation studies were conducted to determine the flowering pattern and yield determinants of two Hybrid Tea rose cultivars in response to seasonal variations under rainfed conditions. The $2 \times 2 \times 4$ factorial experiment arranged in split plot design at three replications was conducted at two seasons (dry and wet) using two cultivars (cv. "Immaculate" and "P.H. Baby", white and red flowers respectively) supplied with poultry manure (PM) application rates at 5,10 and $20 \mathrm{t} / \mathrm{ha}$ where the unfertilized $(0 \mathrm{t} / \mathrm{ha})$ served as control. The result showed that the year two environmental conditions of both experiment I and II significantly improved plant height, number of leaves, number of buds (CNB) and opened flowers (CNF) and flower yield (FYD). "Immaculate" was significantly $(p \leq 0.05)$ taller with more leaves but thinner girth. Although generally lower in NF/NB, and not different in FYD, the "P.H. Baby" had more flowers (CNB and CNF) in experiment I. Except for no significant difference in FYD and lower NF/NB recorded by all manure rates compared to control in experiment II, plants treated with $5 \mathrm{t} / \mathrm{ha}$ PM recorded more flowers (CNB and CNF). Significant first and second order interaction effects ( $\leq \leq 0.05)$ showed that "Immaculate" had taller height and more leaves but "P.H. Baby" had more CNB and CNF, although both were not different in FYD. In addition, plants supplied with 5 t/ha PM rates were better in plant height, number of leaves, CNB and CNF compared to other manure rates. In conclusion, year two environmental conditions supported better crop growth and yield, "Immaculate" grew better vegetatively but both were not different in floral yield, while the $5 \mathrm{t} / \mathrm{ha}$ PM was considered the optimum manure application rate under the rain-fed condition. 


\section{Keywords}

\section{Flowering Pattern, Hybrid Tea Rose, Manure Rates, Seasonal Variations}

\section{Introduction}

Hybrid tea class (Rosa $\times$ hybrida) are selected varieties that are vegetatively propagated for selected traits such as flower bud and flower quality (shape, colour and fragrance), stem length and vase life, and are grown by commercial flower growers for cut-flower market and for the domestic uses and industrial landscaping [1]. However, cultivation and trade in the ornamental plants in Sub-Saharan Africa, especially Nigeria and West Africa are based mainly on garden plants production (80 percent), while the remaining 20 percent in form of cut-flowers are mainly for commercial decorations at special occasions and important ceremonies, but the aspect of gift packages due to less traditional recognition of the relative importance are often in the range of 1 - 3 percent of the total production.

In Nigeria, in particular important production and commercial centres are located in the cosmopolitan city of Lagos in South West Nigeria, alongside other cities in the humid rain forest which include Calabar in South-East and Port-Harcourt in South-South, while other centres characterised by the drier savannah vegetation include Abuja (the Federal Capital City) and Jos Plateau both located in the Middle Belt zone. Despite the abundant and vast expanse of land, labour and natural resources, Nigerian growers are yet to key in to utilize the available opportunities offered by the booming cut-flower trade in Europe. Although for the economic consideration in the attractive income and creation of job opportunities for the teeming youth could become a major player in the cut-flower production as gift packages in the near future.

Economic yield which is the primary concern of growers depends especially on adequate flowering as well as in the satisfactory produce utilization by the consumers [2]. Roses are generally classified as day neutral and flowering is recurrent throughout the year if growing conditions are conducive [3], however, production of quality rose cut-flowers are determined by many factors among which are light levels, plant architecture, temperature, fertilizer timing and applications, choice of cultivar, and pest and disease management [1] [3]. Although water stress as an important flower bud induction mechanism in most tropical climates requires perhaps 2 - 3 months of stress for economic levels of flower bud induction [2] [4]. Nonetheless, although floral intensity (flowers per shoot) increases with accumulated low temperatures, it could also diminish with the presence of crop load and the occurrence of high temperatures, in which the latter may be related to sprouting of flowering buds [2].

Considerable uncertainty still exists on how crop species will respond to matters of high importance such as the observed alterations in global temperature and precipitation patterns [5]-[7] which pose significant threats to existence and productivity of crop species. Strategies to cultivate such a "high tech" demanding crop plant will need to be developed to encourage the massive cultivation alongside attractive yield responses for a sustainable cut-flower trade in tropical environment of Sub-Saharan Africa. Attempts to improve crop yields in tropical environment where lowest yield and low quality are among the major problems confronted by crop growers will require manipulating the important growth factors such as plant/soil nutrition, light and temperature which should be the sole aims of modern day research [8]. This will necessitate development of quality production packages which will include soil-less cultivation, efficient nutrient usage and performance of cultivars required under their own rootstocks which may necessarily include consumer consideration for increased fragrance an aspect under selection by plant breeders [9].

However, most nutrient management systems while concentrating on maximizing yield often neglect to balance the need of the crop with the desire to minimize contamination of the environment [10]. Thus the indiscriminate and excessive application of fertilizers in cropland to obtain high crop yields have been reported to cause serious environmental problems, including soil physical structure deterioration, salt accumulation, secondary salinization, and other effects [11]. Nonetheless, the influence of organic matter on soil biological, chemical and physical properties has been reported to affect crop growth and yield either directly by supplying nutrients or indirectly by modifying soil physical properties.

The applied manure can also affect immobilization and mineralization of $\mathrm{N}$, promote the release of soluble $\mathrm{P}$ 
and accelerate the process of structural K release, making it closer to that needed by the crops [12]-[14]. Apart from this, organic-intensive methods have resulted in higher yields than conventional methods more often for the same crop in the same setting [15]. This is supported by the consistently high yield ratios reported from the developing world when farmers incorporate intensive crop production with various agro-ecological techniques, such as crop rotation, cover cropping, agroforestry, addition of organic fertilizers, or more efficient water management [16] [17].

Although organic manure is strongly influenced by prevailing environmental conditions of temperature and water availability which is reflected in the rate of crop residue or organic waste mineralization [18]-[20] indicating that $\mathrm{N}$ mineralization will be greatest during warmer periods when soils are moist [21]. The relative differences in the release of nutrients from various fertilizers could therefore lead to different $\mathrm{C} / \mathrm{N}$ ratios in plants and this in turn could lead to difference in the production of secondary metabolites [22], which depending on growers primary objective will require resource input manipulation for maximum crop growth and productivity. Most organic farms therefore rely on the sustainable intensification of farm management practices that rely on renewable resources, ecological stability, and biodiversity [23], to increase productivity and lessen environmental degradation [24]-[26].

Environmental regulations of reproductive growth of many tropical and subtropical crops have not been extensively studied [2]. In consideration of these facts, research efforts to evolve an efficient nutrient usage should primarily attempt to investigate crop responses to applied organic manure rates under rain-fed conditions. This will assist to unravel the effects of seasonal variability of rainfall and temperature, and the effect of cloudiness on irradiance both within and between seasons on crop production when adopting organic production methods. The specific objectives of this study therefore include the determination of the interactive effects of rose varieties in response to applied organic soil amendment materials under wet/dry environmental conditions, and the determination of the best plant species-oriented manure application rate to adopt for efficient and effective rose production and productivity under rain-fed condition.

\section{Methods}

\subsection{Description of Experimental Site}

Field experiments were conducted between 2012 and 2014 at the Federal University of Agriculture, Abeokuta, Ogun State, South-western Nigeria (Lat. $7^{\circ} 12^{\prime} \mathrm{N}$, Long. $3^{\circ} 20^{\prime} \mathrm{E}$. Alt. $100 \mathrm{~m}$ a.s.l.). The plot used had previously been cropped with maize and left fallow for three years before this experiment. The prevailing weather of the study area for the duration of the experiment is as shown in Table 1.

For the two phased experiment, the experiment I, conducted in the dry weather recorded for rainfall (417.0 and $262.5 \mathrm{~mm}$ ), Max. Temp. $\left(32.3^{\circ} \mathrm{C}\right.$ and $\left.31.7^{\circ} \mathrm{C}\right)$, Min. Temp. $\left(22.6^{\circ} \mathrm{C}\right.$ and $\left.22.9^{\circ} \mathrm{C}\right)$, evaporation $(14.1$ and 13.7 $\mathrm{mm}$ ) and sunshine duration (21.4 and $22.0 \mathrm{~h}$ ) during Sept-Dec. of 2012 and 2013 in years one and two respectively (Table 1). For experiment II, conducted in the wet weather recorded for rainfall (405.7 and $490.3 \mathrm{~mm}$ ), Max. Temp. (33.5 ${ }^{\circ} \mathrm{C}$ and $\left.33.3^{\circ} \mathrm{C}\right)$, Min. Temp. $\left(23.4^{\circ} \mathrm{C}\right.$ and $\left.23.5^{\circ} \mathrm{C}\right)$, evaporation $(24.5$ and $20.7 \mathrm{~mm})$ and sunshine duration (33.3 and 35.3 h) during Mar-June of 2013 and 2014 in years one and two respectively (Table 1). Except for the reduction in year two values observed for both rainfall and maximum temperature in experiment I, and for evaporation of both experiment I and II, all observed weather parameters in both experiments I and II experienced marginal or substantial increased in values. This could have accounted for the seasonal variation in the environment. The results of the analysis of the pre-cropping physico-chemical property of the site and of the poultry manure used are presented in Table 2. Except for the lower $\mathrm{P}$ and $\mathrm{Zn}$ values, the soil was high in $\mathrm{N}$ and $\mathrm{K}$ values, and high in micro-nutrient $\mathrm{Na}, \mathrm{Mg}, \mathrm{Mn}$ and Fe but moderate in ECEC and organic carbon [27] (Sobulo and Osiname, 1981).

\subsection{Experimental Design}

The two hybrid tea rose cultivars selected for the study were cv. "Immaculate" and "P.H. Baby" which were white and red flowered respectively. The plants grown under normal field conditions were supplied with manure application rates of 5, 10 and $20 \mathrm{t} /$ ha poultry manure (PM) where the unfertilized plot ( $0 \mathrm{t} / \mathrm{ha})$ served as control. The $2 \times 2 \times 4$ factorial experiment arranged in split plot design was replicated three times for the two different seasons. 
Table 1. Rainfall (mm), Max. and Min. temperature $\left({ }^{\circ} \mathrm{C}\right)$, Evapo-Transpiration $(\mathrm{mm})$ and sunshine hours (h) data for the cropping Period 2012-2014.

\begin{tabular}{|c|c|c|c|c|c|c|c|c|c|c|c|c|c|c|c|}
\hline \multirow{3}{*}{$\begin{array}{c}\text { Parameters } \\
\text { /Year }\end{array}$} & \multicolumn{9}{|c|}{ Weather data for 2012-2014 } & & & & & & \\
\hline & \multicolumn{3}{|c|}{ Rainfall (mm) } & \multicolumn{3}{|c|}{ Max temp ${ }^{\circ} \mathrm{C}$} & \multicolumn{3}{|c|}{ Min temp ${ }^{\circ} \mathrm{C}$} & \multicolumn{3}{|c|}{ Evaporation (mm) } & \multicolumn{3}{|c|}{ Sunshine Hours } \\
\hline & 12 & 13 & 14 & 12 & 13 & 14 & 12 & 13 & 14 & 12 & 13 & 14 & 12 & 13 & 14 \\
\hline Jan & 0 & 39.8 & 8.2 & 34 & 36 & 34.2 & 20 & 21.6 & 23.6 & 3.8 & 4.5 & 4.2 & 4.2 & 5.9 & 6.1 \\
\hline Feb & 67.2 & 23.5 & 15.5 & 33.9 & 35.4 & 35.2 & 23.7 & 23.9 & 23.4 & 4.13 & 5.3 & 4.5 & 4.5 & 5.5 & 5.8 \\
\hline Mar & 67.7 & 78.1 & 149.1 & 34.3 & 34.9 & 34.0 & 23.9 & 24.6 & 23.6 & 4.4 & 4.7 & 3.1 & 5.1 & 5.1 & 6.0 \\
\hline Apr & 80.1 & 82.4 & 87.2 & 33.1 & 31.4 & 32.9 & 23.9 & 23.2 & 23.5 & 4.2 & 3.6 & 3.7 & 5.7 & 5.8 & 5.7 \\
\hline May & 115.3 & 128.2 & 113.8 & 32.2 & 32.1 & 32.1 & 23.1 & 23.5 & 23.4 & 4.3 & 3.6 & 2.9 & 4.8 & 5.7 & 5.8 \\
\hline Jun & 225.1 & 53.7 & 116.5 & 30.8 & 31 & 31.5 & 23 & 23.3 & 23.4 & 2.0 & 2.8 & 2.3 & 3.9 & 5.3 & 5.9 \\
\hline Jul & 155.4 & 202.6 & 90.7 & 29.9 & 28.7 & 29.9 & 22.2 & 22.3 & 23.3 & 1.8 & 1.2 & 1.3 & 4.0 & 3.0 & 3.8 \\
\hline Aug & 36.3 & 35.2 & 92.7 & 28.4 & 28.6 & 29.1 & 22.6 & 21.1 & 22.1 & 2.5 & 2.6 & 0.8 & 2.7 & 3.1 & 2.3 \\
\hline Sep & 181.4 & 136 & 160.8 & 29.6 & 28.9 & 29.8 & 22.7 & 22.4 & 22.7 & 3.0 & 3.0 & 1.8 & 4.0 & 4.3 & 3.2 \\
\hline Oct & 184.7 & 94.4 & 205.9 & 32.2 & 31.7 & 30.5 & 22.1 & 23.1 & 22.0 & 3.6 & 2.4 & 1.4 & 5.7 & 5.0 & 5.3 \\
\hline Nov & 49.6 & 15.6 & 17.6 & 33.0 & 33.1 & 32.4 & 23.3 & 23.5 & 22.6 & 3.8 & 4.2 & 3.5 & 5.4 & 6.5 & 5.3 \\
\hline Dec & 1.3 & 16.5 & - & 34.5 & 33 & - & 22.3 & 22.4 & - & 3.7 & 4.1 & - & 6.3 & 6.2 & - \\
\hline \multirow[t]{2}{*}{ Expt. 1} & Year I & Year II & & \multicolumn{4}{|c|}{ Year I Year II } & \multicolumn{4}{|c|}{ Year I Year II } & \multicolumn{4}{|c|}{ Year I Year II } \\
\hline & 417.0 & 262.5 & - & & 32.3 & 31.7 & - & & 22.6 & 22.9 & - & & 14.1 & 13.7 & - \\
\hline \multirow[t]{2}{*}{ Expt. 2} & & Year I & Year II & & \multicolumn{4}{|c|}{ Year I Year II } & \multicolumn{4}{|c|}{ Year I Year II } & \multicolumn{3}{|c|}{ Year I Year II } \\
\hline & - & 405.7 & 490.3 & & - & 33.5 & 33.3 & & - & 23.4 & 23.5 & & - & 24.5 & 20.7 \\
\hline
\end{tabular}

Bold figures indicate the data obtained for the period of experiment. Summary for Expt. 1 and 2 is indicated below the table, and totaled for Rainfall,

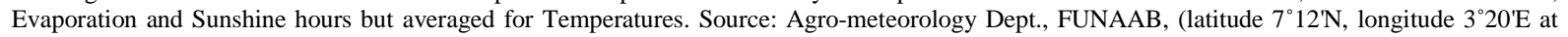
$100 \mathrm{~m}$ above sea level).

Table 2. The physico-chemical properties of the soil and manure used.

\begin{tabular}{|c|c|c|c|}
\hline \multirow{2}{*}{ Parameters } & \multicolumn{2}{|c|}{ Soil Sample } & \multirow{2}{*}{ Poultry Manure } \\
\hline & Experiment I & Experiment II & \\
\hline $\mathrm{pH}\left(\mathrm{H}_{2} \mathrm{O}\right)$ & 6.15 & 6.72 & 7.48 \\
\hline Zn (ppm) & - & - & 3.05 \\
\hline $\mathrm{Fe}(\mathrm{ppm})$ & 0.87 & 0.92 & 0.94 \\
\hline $\mathrm{Cu}(\mathrm{ppm})$ & 1.82 & 1.96 & 2.8 \\
\hline Mn (ppm) & 113.5 & 62.9 & 295 \\
\hline $\mathrm{Mg}(\mathrm{cmol} / \mathrm{kg})$ & 1.34 & 0.38 & 1.96 \\
\hline $\mathrm{Ca}(\mathrm{cmol} / \mathrm{kg})$ & 0.95 & 1.17 & 8.43 \\
\hline $\mathrm{Na}(\mathrm{cmol} / \mathrm{kg})$ & 3.12 & 0.45 & - \\
\hline $\mathrm{K}(\mathrm{cmol} / \mathrm{kg})$ & 0.98 & 0.45 & 0.35 \\
\hline Carbon (\%) & 1.54 & 0.76 & 4.95 \\
\hline Nitrogen (\%) & 2.40 & 0.055 & 0.46 \\
\hline Avail. P (ppm) & 1.80 & 10.05 & 2.20 \\
\hline Sand (\%) & 87.90 & 73.40 & \\
\hline Silt (\%) & 7.50 & 14.60 & \\
\hline Clay (\%) & 4.60 & 7.30 & \\
\hline Textural Class & Sandy & Loamy Sand & \\
\hline
\end{tabular}


The two phased seasonal studies adopted a methodology of repeating both dry and wet season cultivation in a two year consecutive study. The experiment I conducted between September and December of 2012 and repeated same period in 2013 utilized juvenile seedlings obtained from a commercial grower in Ibadan, Nigeria while the experiment II conducted between March and June 2013 and repeated same period in 2014 utilized the 6-month-old plants from experiment I. The experimental unit comprised of one plant per plot and the plants were spaced at $1 \mathrm{~m}$ apart between rows and within rows. The manure was applied in ring method at $30 \mathrm{~cm}$ away from the plant. The experiment was maintained by regular application of water to sustain the plant during dry weather, regular weeding of the plots and organic methods of controlling pest and disease organisms [28].

\subsection{Data Collection and Analysis}

The data collection was done weekly by measurement of crop growth parameters such as plant height (cm), stem girth $(\mathrm{cm})$ and number of leaves, and the flowering phenology variables which include number of flower buds per shoot, number of flowers opened per flowering bud, and floral intensity (number of flowers per shoot), and actual flower yield (kg/ha). The three factor experiment arranged in split plot design was analyzed using analysis of variance method [29]. The means were compared by the least significant method at $\mathrm{p} \leq 0.05$ [30]. The various trend and relationships were presented using graphical methods, correlation/regression analysis to describe level of association/relationship [29].

\section{Result}

\subsection{Vegetative Growth Responses}

Significant differences ( $\mathrm{p} \leq 0.05$ ) were obtained for the season effect where in experiment I and II, the year two environmental condition significantly improved crop responses in plant height and number of leaves but caused retardation effects on stem girth (Table 3). Significant differences ( $\leq 0.05$ ) were obtained for species responses where in experiment I and II, “Immaculate" performed better than "P.H. Baby" in possessing taller height and more leaves only, although there was no significant difference in stem girth of experiment I, but "P.H. Baby” had thicker girth in experiment II (Table 3). Also significant differences ( $\leq \leq 0.05$ ) were obtained for manure influence where in experiment I and II, plants treated with both 5 t/ha and 10 t/ha PM were taller and had more leaves in experiment I, but plants treated with 5 t/ha PM had thicker girth in experiment I, and taller height, thicker girth and more leaves in experiment II compared to those with $10 \mathrm{t} / \mathrm{ha} \mathrm{PM}$ and other treatments (Table 3).

\subsection{Flowering and Flower Yield}

Significant differences ( $\mathrm{p} \leq 0.05$ ) were obtained for the season effect where in experiment I and II, the year two environmental condition significantly improved flower bud formation (NB) (Figure 1(a) \& Figure 1(b)) and produced more opened flowers (NF) with increasing margin in experiment II compared to experiment I but with depression in experiment II (Figure 2(a) \& Figure 2(b)). Except for the non-existence of a depression the same trend observed for weekly count was replicated in the cumulative count in both number of flower buds (CNB) and number of opened flowers (CNF) in experiment I and II (Table 4). Although the year two recorded more CNB and CNF compared to year one in both experiment I and II, and despite the no significant difference in flower yield (FYD) of experiment I, it recorded heavier FYD in experiment II, but was lower in number of flowers per flower buds (NF/NB) in experiment II (Table 4) (Figure 3(a) \& Figure 3(b)).

Significant differences ( $\mathrm{p} \leq 0.05$ ) were obtained for species type where the "P.H. Baby" although lower in vegetative growth most of the times, and except for a reversal in trend causing more flowers in Immaculate at 16 w.a.t, of experiment I, the "P.H. Baby" recorded significantly more NB (Figure 4(a) \& Figure 4(b)) in both weekly and cumulative count compared to the "Immaculate”. Although there was a reversal at 16 w.a.t. of experiment I and 40 w.a.t of experiment II where "Immaculate" recorded significantly higher compared to "P.H. Baby” there was no significant difference in NF among both cultivars (Figure 5(a) \& Figure 5(b), Figure 6(a) \& Figure 6(b)). Also "P.H. Baby" had more flowers (CNB, CNF and FYD) in experiment I, but there was no significant difference among both in flowering pattern in experiment II (Table 4).

Significant differences ( $\leq 0.05$ ) were obtained for the responses to manure rate which showed an irregularity in observed flowering pattern (NB and NF) (Figure 7(a) \& Figure 7(b), Figure 8(a) \& Figure 8(b)) in experi- 
Table 3. Vegetative growth behaviours of rose cultivars in response to seasonal variation and manure application rates at 16 and 40 w.a.t.

\begin{tabular}{|c|c|c|c|c|c|c|}
\hline \multirow[b]{2}{*}{ Treatments } & \multicolumn{3}{|c|}{ Experiment one } & \multicolumn{3}{|c|}{ Experiment two } \\
\hline & Plant height (cm) & Stem girth $(\mathrm{cm})$ & $\begin{array}{l}\text { Number } \\
\text { of leaves }\end{array}$ & Plant height (cm) & $\begin{array}{l}\text { Stem girth } \\
\text { (cm) }\end{array}$ & Number of leaves \\
\hline & $16^{\dagger}$ & $16^{\dagger}$ & $16^{\dagger}$ & $40^{\dagger}$ & $40^{\dagger}$ & $40^{\dagger}$ \\
\hline \multicolumn{7}{|l|}{ Season effect } \\
\hline Year 1 & 27.2 & 5.2 & 73.0 & 37.0 & 7.9 & 113.3 \\
\hline Year 2 & 80.0 & 1.3 & 125.7 & 137.6 & 2.8 & 194.3 \\
\hline LSD 0.05 & 3.64 & 0.10 & 22.35 & 5.30 & 0.31 & 27.76 \\
\hline \multicolumn{7}{|l|}{ Specie effect } \\
\hline Immaculate & 65.2 & 3.1 & 122.1 & 103.8 & 4.4 & 173.8 \\
\hline P.H. Baby & 41.9 & 3.4 & 76.6 & 67.9 & 6.2 & 133.8 \\
\hline LSD 0.05 & 4.60 & 0.36 & 12.65 & 4.52 & 0.38 & 12.54 \\
\hline \multicolumn{7}{|l|}{ Manure effect } \\
\hline 0 t/ha PM & 56.4 & 3.2 & 92.3 & 86.4 & 4.6 & 142.5 \\
\hline 5 t/ha PM & 61.9 & 3.9 & 116.2 & 110.2 & 7.8 & 190.3 \\
\hline 10 t/ha PM & 62.6 & 3.2 & 124.4 & 89.2 & 4.8 & 176.1 \\
\hline 20 t/ha PM & 33.5 & 2.7 & 64.6 & 61.2 & 4.2 & 106.4 \\
\hline LSD 0.05 & 2.34 & 0.33 & 10.77 & 3.41 & 0.32 & 11.20 \\
\hline \multicolumn{7}{|l|}{ Interactions } \\
\hline Yr.*Sp. & $* *$ & ns & ** & ** & ns & ** \\
\hline Yr.*PM & ** & ns & ** & ** & ${ }^{* *}$ & ** \\
\hline Sp.*PM & ** & ns & * & ** & $* *$ & $*$ \\
\hline Yr.*Sp.*PM & $* *$ & ns & ns & ** & ns & * \\
\hline
\end{tabular}

${ }^{* *}=$ significant at $0.01,{ }^{*}=$ significant at $0.05, \mathrm{~ns}=$ not significant, ${ }^{\dagger}=$ weeks after transplanting.

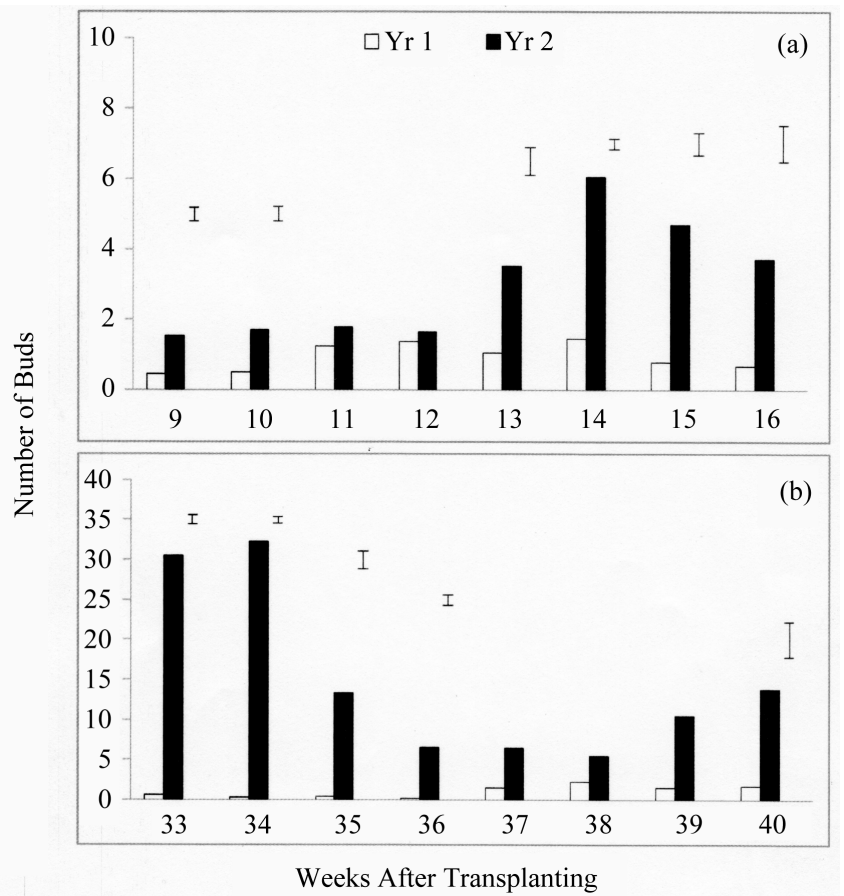

Figure 1. Number of flower buds of rose cultivars in response to season- $-\square$ Year 1 and $\square$ Year 2 at the two growth stages (a) the juvenile seedlings stage and (b) 6-month-old plants stage. Means were separated by LSD at $\mathrm{p} \leq 0.05$. 


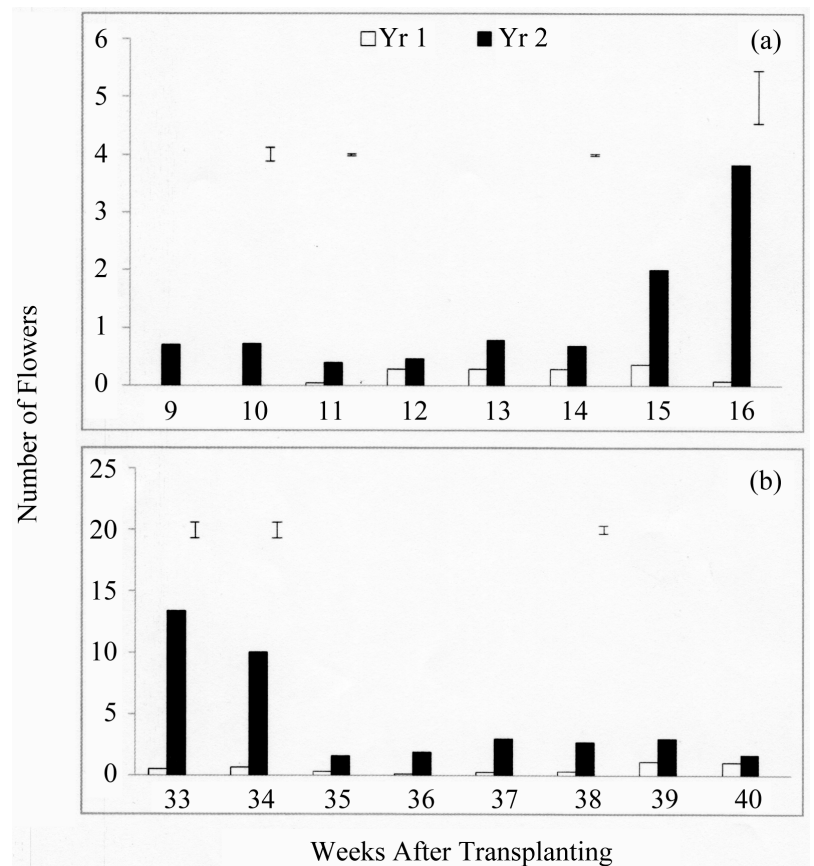

Figure 2. Number of opened flowers of rose cultivars in response to season- $\square$ Year 1 and $\mathbf{y e a r} 2$ at the two growth stages (a) the juvenile seedlings stage and (b) 6-month-old plants stage. Means were separated by LSD at $\mathrm{p} \leq 0.05$.

Table 4. Flowering pattern and yield attributes of rose cultivars in response to seasonal variation and manure application rates at 16 and 40 w.a.t.

\begin{tabular}{|c|c|c|c|c|c|c|c|c|}
\hline \multirow[b]{2}{*}{ Treatments } & \multicolumn{3}{|c|}{ Experiment one } & \multicolumn{5}{|c|}{ Experiment two } \\
\hline & $\begin{array}{l}\text { Cum. number } \\
\text { of flower buds }\end{array}$ & $\begin{array}{l}\text { Cum. number } \\
\text { of opened } \\
\text { flowers }\end{array}$ & $\begin{array}{l}\text { Number of } \\
\text { flowers/buds }\end{array}$ & $\begin{array}{c}\text { Flower yield } \\
\text { (kg/ha) }\end{array}$ & $\begin{array}{l}\text { Cum. number } \\
\text { of flower } \\
\text { buds }\end{array}$ & $\begin{array}{l}\text { Cum. number } \\
\text { of opened } \\
\text { flowers }\end{array}$ & $\begin{array}{l}\text { Number of } \\
\text { flowers/buds }\end{array}$ & $\begin{array}{c}\text { Flower yield } \\
\text { (kg/ha) }\end{array}$ \\
\hline & $16^{\dagger}$ & $16^{\dagger}$ & $16^{\dagger}$ & $16^{\dagger}$ & $40^{\dagger}$ & $40^{\dagger}$ & $40^{\dagger}$ & $40^{\dagger}$ \\
\hline \multicolumn{9}{|l|}{ Season effect } \\
\hline Year 1 & 7.5 & 1.4 & 0.2 & 0.99 & 8.8 & 4.3 & 0.6 & 27.5 \\
\hline Year 2 & 24.7 & 9.6 & 0.3 & 7.37 & 119.1 & 37.2 & 0.3 & 233.2 \\
\hline LSD 0.05 & 1.47 & 0.70 & 0.08 & 9.80 & 9.32 & 3.51 & 0.09 & 20.19 \\
\hline \multicolumn{9}{|l|}{ Specie effect } \\
\hline Immaculate & 11.0 & 4.0 & 0.3 & 2.56 & 61.7 & 20.9 & 0.5 & 128.0 \\
\hline P.H. Baby & 21.3 & 6.9 & 0.2 & 5.81 & 66.2 & 20.7 & 0.4 & 132.7 \\
\hline LSD 0.05 & 5.21 & 2.82 & 0.05 & ns & ns & ns & 0.04 & ns \\
\hline \multicolumn{9}{|l|}{ Manure effect } \\
\hline 0 t/ha PM & 7.6 & 3.4 & 0.2 & 1.68 & 34.0 & 17.6 & 0.6 & 81.6 \\
\hline 5 t/ha PM & 24.2 & 9.4 & 0.4 & 5.63 & 100.8 & 26.7 & 0.4 & 158.5 \\
\hline 10 t/ha PM & 20.2 & 4.6 & 0.1 & 4.98 & 79.6 & 22.0 & 0.4 & 152.3 \\
\hline 20 t/ha PM & 12.5 & 4.5 & 0.3 & 4.44 & 41.3 & 16.9 & 0.4 & 129.0 \\
\hline LSD 0.05 & 3.67 & 1.54 & 0.06 & ns & 9.83 & 4.93 & 0.07 & 30.93 \\
\hline \multicolumn{9}{|l|}{ Interactions } \\
\hline Yr.*Sp. & ns & ns & ns & ns & ns & ns & ns & ns \\
\hline Yr.*PM & ns & ns & ns & ns & $* *$ & ns & ns & ns \\
\hline Sp.*PM & ns & $*$ & ns & ns & ns & ns & ns & ns \\
\hline Yr.*Sp.*PM & ns & ns & ns & ns & ns & ns & ns & ns \\
\hline
\end{tabular}

${ }^{* *}=$ significant at $0.01,{ }^{*}=$ significant at $0.05, \mathrm{~ns}=$ not significant, ${ }^{\dagger}=$ weeks after transplanting. 


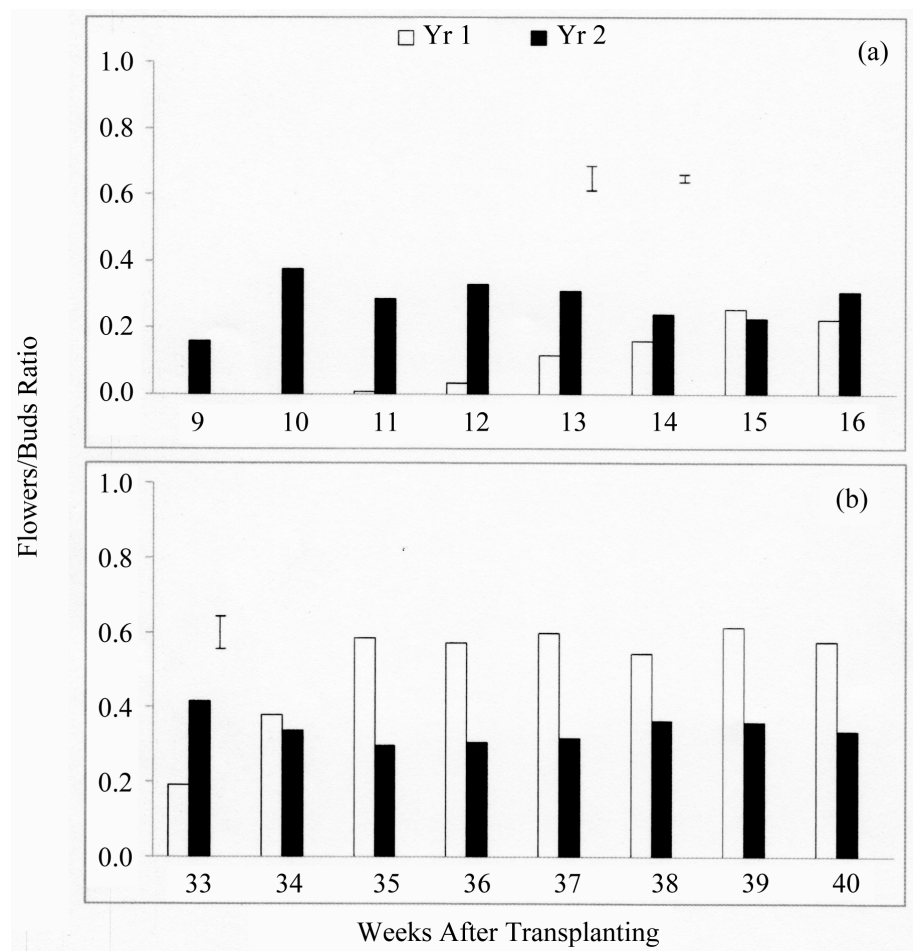

Figure 3. Number of Flower/Bud Ratio of rose cultivars in response to season$\square$ Year 1 and $\mathbf{a}$ Year 2 at the two growth stages (a) the juvenile seedlings stage and (b) 6-month-old plants stage. Means were separated by LSD at $\mathrm{p} \leq 0.05$.

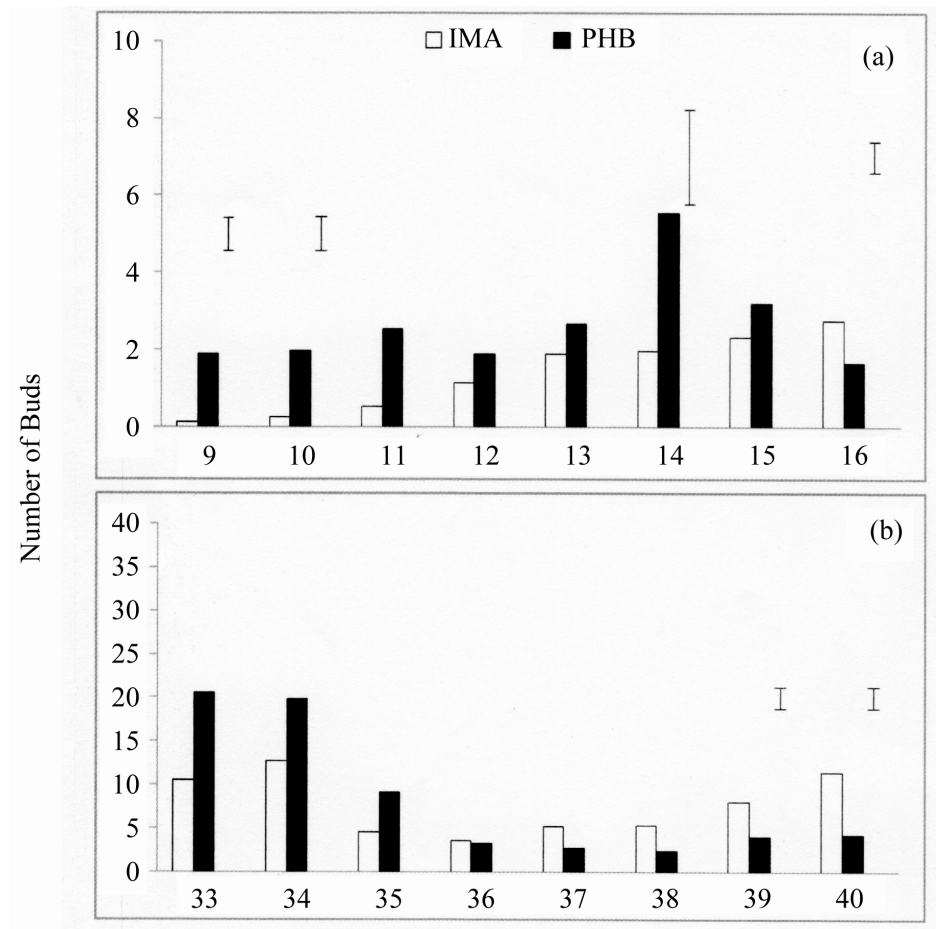

Weeks After Transplanting

Figure 4. Number of flower buds of rose cultivars in response to variety- $\square$ IMA and $\mathbf{\text { PHB }}$ at the two growth stages (a) the juvenile seedlings stage and (b) 6 -month-old plants stage. Means were separated by LSD at $\mathrm{p} \leq 0.05$. 


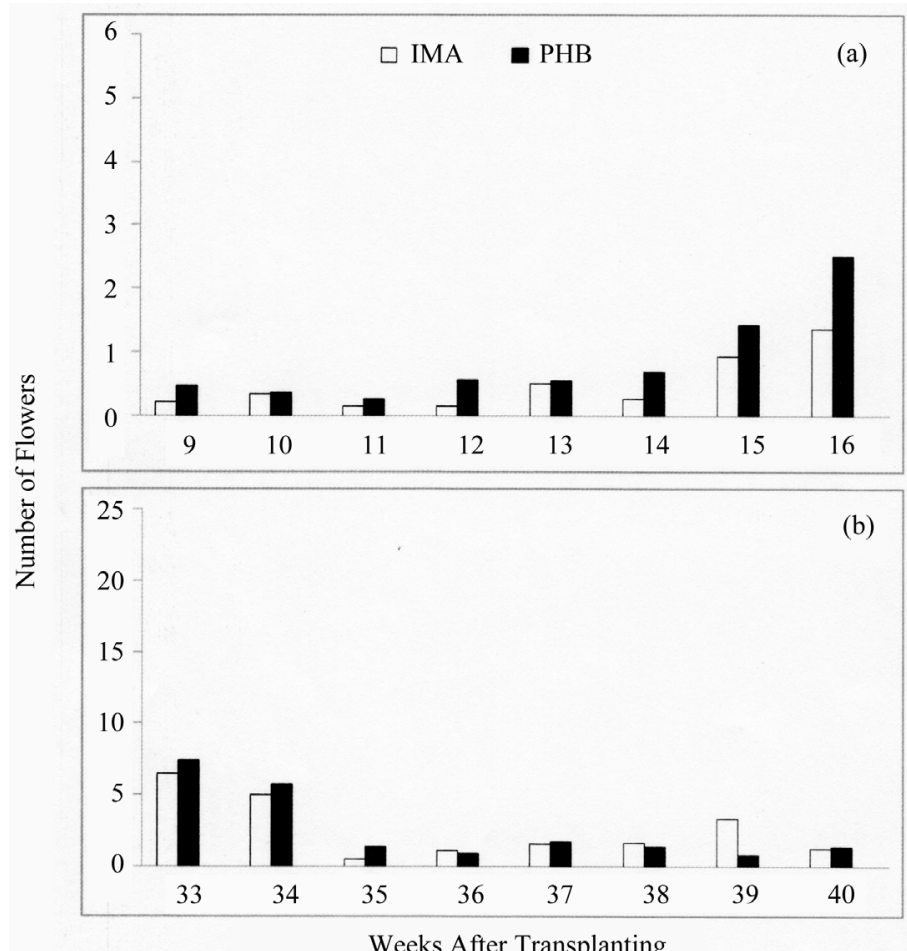

Figure 5. Number of opened flowers of rose cultivars in response to variety- $\square$

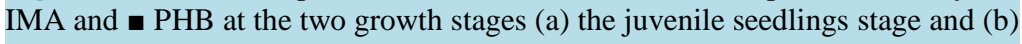
6 -month-old plants stage. Means were separated by LSD at $\mathrm{p} \leq 0.05$.

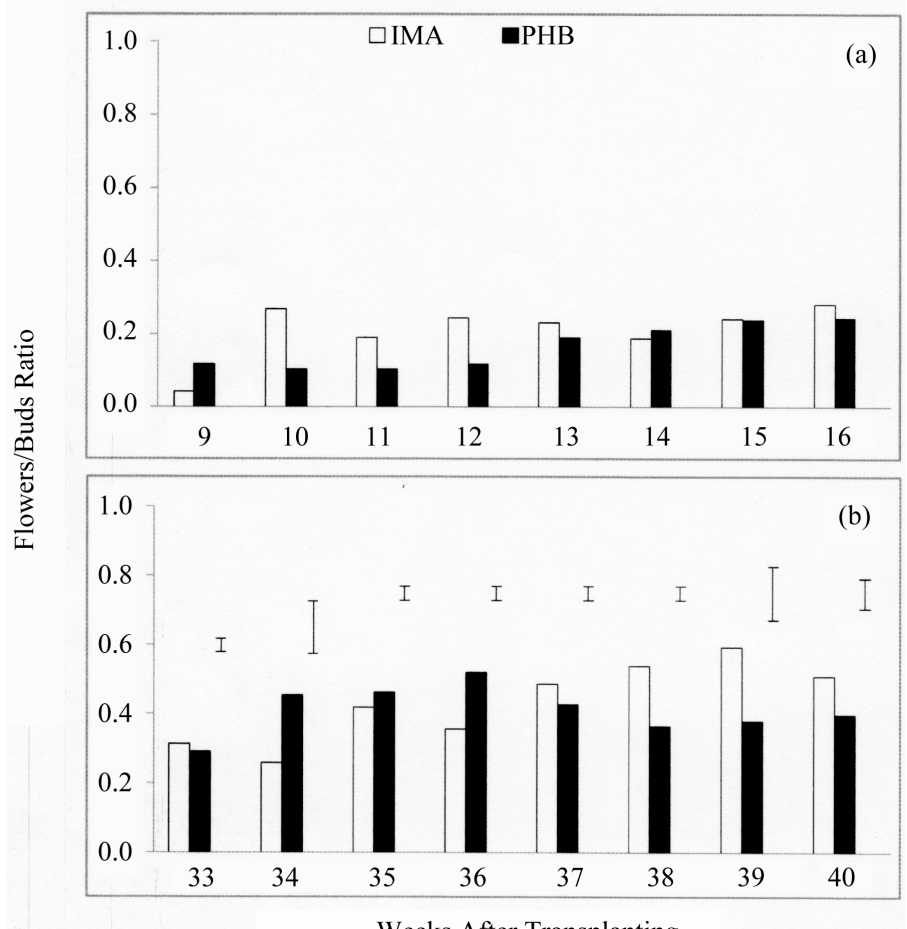

Weeks After Transplanting

Figure 6. Number of Flower/Bud Ratio of rose cultivars in response to variety$\square$ IMA and - PHB at the two growth stages (a) the juvenile seedlings stage and (b) 6-month-old plants stage. Means were separated by LSD at $\mathrm{p} \leq 0.05$. 


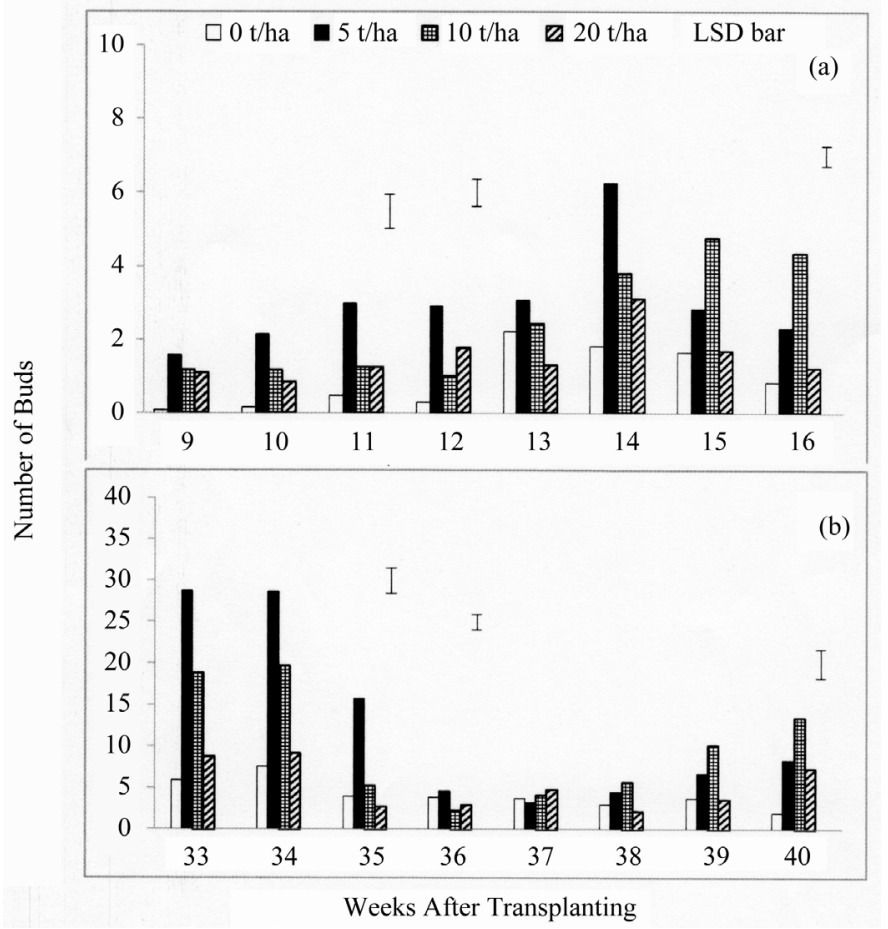

Figure 7. Number of Flower Buds of rose cultivars in response to $\square 0 \mathrm{t} / \mathrm{ha}$, $\square$ t/ha, 10 t/ha and $\square 20$ t/ha at the two growth stages (a) the juvenile seedlings stage and (b) 6-month-old plants stage. Means were separated by LSD at p $\leq 0.05$.

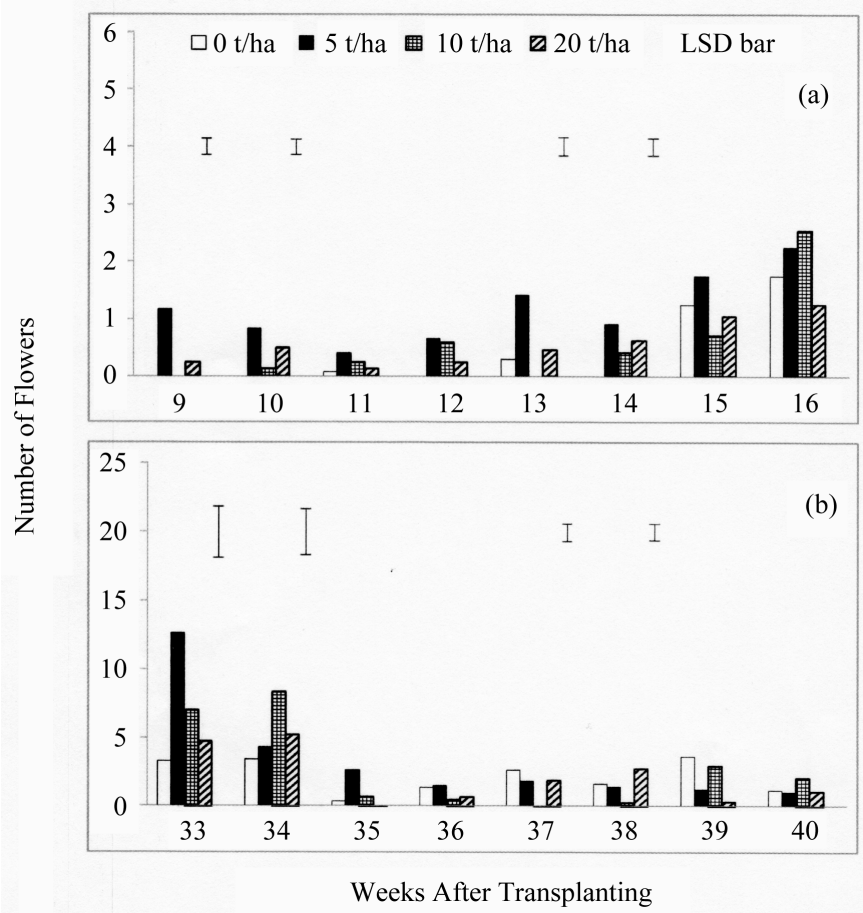

Figure 8. Number of opened flowers of rose cultivars in response to manure rates— $\square 0 \mathrm{t} / \mathrm{ha}, \square 5 \mathrm{t} / \mathrm{ha}$, 田 $10 \mathrm{t} / \mathrm{ha}$ and $\square 20 \mathrm{t} / \mathrm{ha}$ at the two growth stages (a) the juvenile seedlings stage and (b) 6-month-old plants stage. Means were separated by LSD at $\mathrm{p} \leq 0.05$. 
ment I and II but consistently higher NF/NB (Figure 9(a) \& Figure 9(b)) were recorded for plants treated with $5 \mathrm{t} / \mathrm{ha} \mathrm{PM}$ at onset of flowering in experiment I, but no significant difference observed at 16w.a.t among the treatments in experiment I, and throughout in experiment II. Nonetheless, plants supplied with $5 \mathrm{t} / \mathrm{ha}$ PM were higher most of the times in NB which was significant at 11 - 12 w.a.t. and 35 - 36 w.a.t. and for NF at 13 w.a.t. and 33 w.a.t, however, an eventual significant higher response was observed for plants treated with $10 \mathrm{t} / \mathrm{ha}$ at 40 w.a.t. (NB) and 20w.a.t. (NF) (Figure 7(a) \& Figure 7(b), Figure 8(a) \& Figure 8(b)). Although there was no significant difference in FYD recorded for experiment I, all manure rates were significantly higher in the influence on FYD in experiment II. The 5 t/ha PM was significantly higher in flower production (CNB, CNF and $\mathrm{NF} / \mathrm{NB}$ ) in both experiment I and II, and except for the no significant difference between $0 \mathrm{t} / \mathrm{ha}$ and $20 \mathrm{t} / \mathrm{ha}$ in CNB and CNF in experiment II, all manure rates were significant higher compared to 0 t/ha (Table 4) (Figure 9(a) \& Figure 9(b)).

\subsection{Season, Species and Manure Interaction Effects on Growth and Yield}

Significant season $\times$ species $(\mathrm{p} \leq 0.05)$ and significant season $\times$ species $\times$ manure rate $(\mathrm{p} \leq 0.05)$ interaction effects recorded consistently taller height and more leaves for the "Immaculate" compared to "P.H. Baby" in both experiment I and II, but though "Immaculate" was taller with more leaves in year two, the "P.H. Baby" had more leaves compared to the "Immaculate" in year one (Table 5). The plants in "Immaculate" treated with 5 and 10 t/ha PM were taller in experiment I and had more leaves in experiment II, while only plants in "Immaculate" treated with $5 \mathrm{t} /$ ha were taller in experiment II. Nonetheless, the plants in "P.H. Baby" treated with $10 \mathrm{t} / \mathrm{ha}$ were taller in experiment I while plants in "P.H. Baby" treated with $5 \mathrm{t} /$ ha were taller with more leaves in experiment II (Table 6).

Significant season $\times$ manure rate $(\mathrm{p} \leq 0.05)$ and significant species $\times$ manure rate $(\mathrm{p} \leq 0.05)$ interaction effects

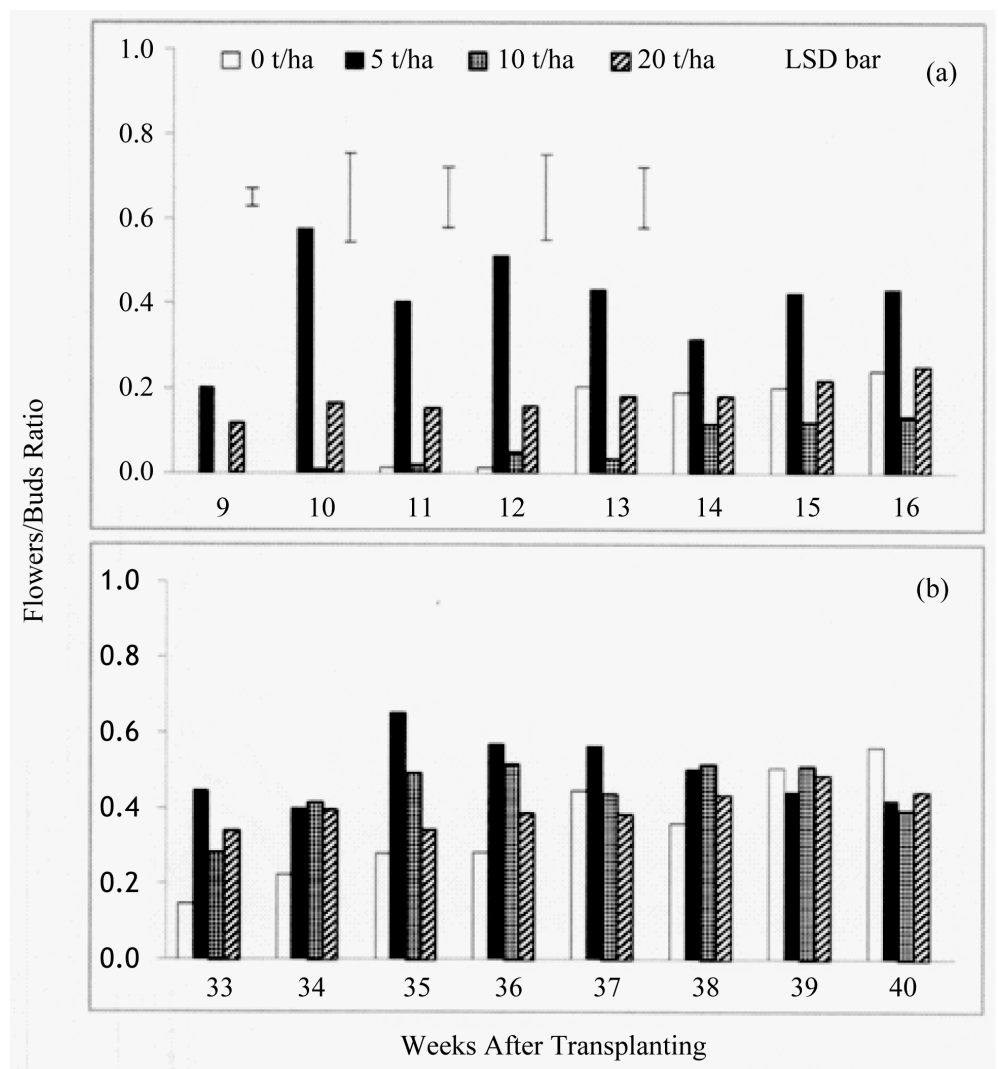

Figure 9. Number of Flower/Bud Ratio of rose cultivars in response to manure rates- $\square \mathrm{t} / \mathrm{ha}$, $5 \mathrm{t} / \mathrm{ha}$, 田 $10 \mathrm{t} / \mathrm{ha}$ and $\mathbb{Z} 20 \mathrm{t} / \mathrm{ha}$ at the two growth stages (a) the juvenile seedlings stage and (b) 6-month-old plants stage. Means were separated by $L S D$ at $\mathrm{p} \leq 0.05$. 
Table 5. Season $\times$ species interaction effects of rose cultivars in response to seasonal variation and manure application rates at 16 and 40 w.a.t.

\begin{tabular}{|c|c|c|c|c|c|c|c|}
\hline \multirow[b]{2}{*}{ Season } & \multirow[b]{2}{*}{ Species } & \multicolumn{3}{|c|}{ Experiment one } & \multicolumn{3}{|c|}{ Experiment two } \\
\hline & & $\begin{array}{l}\text { Plant height } \\
\text { (cm) }\end{array}$ & $\begin{array}{l}\text { Stem girth } \\
\text { (cm) }\end{array}$ & $\begin{array}{c}\text { Number of } \\
\text { leaves }\end{array}$ & $\begin{array}{l}\text { Plant height } \\
\text { (cm) }\end{array}$ & $\begin{array}{l}\text { Stem girth } \\
\text { (cm) }\end{array}$ & $\begin{array}{c}\text { Number of } \\
\text { leaves }\end{array}$ \\
\hline & & \multicolumn{3}{|c|}{$16^{\dagger}$} & \multicolumn{3}{|c|}{$40^{\dagger}$} \\
\hline First & Immaculate & $26.2 \mathrm{c}$ & 4.7(ns) & $66.8 c$ & $36.1 c$ & 7.0 (ns) & $103.7 d$ \\
\hline First & P.H. Baby & $28.2 \mathrm{c}$ & 5.7(ns) & $79.3 b$ & $38.0 \mathrm{c}$ & 8.7 (ns) & $122.9 \mathrm{c}$ \\
\hline Second & Immaculate & 104.3a & $1.5(\mathrm{~ns})$ & $177.5 \mathrm{a}$ & 171.6a & 1.8 (ns) & $244.0 \mathrm{a}$ \\
\hline Second & P.H. Baby & $55.7 \mathrm{~b}$ & $1.2(\mathrm{~ns})$ & 73.9bc & $100.5 b$ & 3.8 (ns) & $144.7 b$ \\
\hline
\end{tabular}

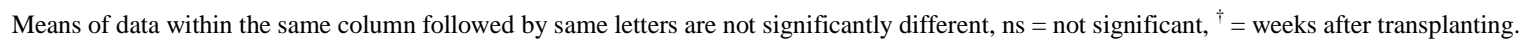

Table 6. Season $\times$ species $\times$ manure rate interaction effects of rose cultivars in response to seasonal variation and manure application rates at 16 and 40 w.a.t.

\begin{tabular}{|c|c|c|c|c|c|c|c|c|}
\hline \multirow[b]{2}{*}{ Season } & \multirow[b]{2}{*}{ Species } & \multirow{3}{*}{ Manure rate } & \multicolumn{3}{|c|}{ Experiment one } & \multicolumn{3}{|c|}{ Experiment two } \\
\hline & & & $\begin{array}{l}\text { Plant height } \\
\text { (cm) }\end{array}$ & $\begin{array}{l}\text { Number of } \\
\text { leaves }\end{array}$ & $\begin{array}{l}\text { Cum. No. of } \\
\text { opened } \\
\text { flowers }\end{array}$ & $\begin{array}{l}\text { Plant height } \\
\quad(\mathrm{cm})\end{array}$ & $\begin{array}{l}\text { Number of } \\
\text { leaves }\end{array}$ & $\begin{array}{l}\text { Cum. No. of } \\
\text { opened } \\
\text { flowers }\end{array}$ \\
\hline & & & \multicolumn{3}{|c|}{$16^{\dagger}$} & \multicolumn{3}{|c|}{$40^{\dagger}$} \\
\hline First & Immaculate & 0 t/ha PM & $22.6 \mathrm{~h}$ & 76.3 (ns) & 1.0 (ns) & $32.9 \mathrm{j}$ & $117.7 \mathrm{e}$ & 4.3 (ns) \\
\hline First & Immaculate & 5 t/ha PM & $30.0 \mathrm{~g}$ & 59.0 (ns) & 1.0 (ns) & $37.9 \mathrm{i}$ & $96.0 f$ & 2.3 (ns) \\
\hline First & Immaculate & 10 t/ha PM & $22.4 \mathrm{~h}$ & 55.0 (ns) & 0.3 (ns) & $33.5 \mathrm{j}$ & 91.0f & 4.3 (ns) \\
\hline First & Immaculate & 20 t/ha PM & $29.6 \mathrm{~g}$ & 76.7 (ns) & $1.0(\mathrm{~ns})$ & $40.0 \mathrm{i}$ & $110.0 \mathrm{e}$ & 2.7 (ns) \\
\hline First & P.H. Baby & 0 t/ha PM & $22.9 \mathrm{~h}$ & 40.3 (ns) & 1.0 (ns) & 31.6j & $82.3 \mathrm{f}$ & 5.0 (ns) \\
\hline First & P.H. Baby & 5 t/ha PM & $30.3 f g$ & 106.0 (ns) & 3.0 (ns) & $45.7 \mathrm{~h}$ & $146.0 \mathrm{~d}$ & 7.0 (ns) \\
\hline First & P.H. Baby & 10 t/ha PM & $32.3 f g$ & 84.7 (ns) & 1.7 (ns) & $36.8 \mathrm{i}$ & $140.3 d$ & 5.0 (ns) \\
\hline First & P.H. Baby & 20 t/ha PM & $27.3 g$ & 86.3 (ns) & 2.0 (ns) & $37.9 \mathrm{i}$ & $123.0 \mathrm{e}$ & 4.0 (ns) \\
\hline Second & Immaculate & 0 t/ha PM & $124.5 b$ & 207.5 (ns) & 11.0 (ns) & $193.0 \mathrm{~b}$ & $259.7 b$ & 47.0 (ns) \\
\hline Second & Immaculate & 5 t/ha PM & $130.0 \mathrm{a}$ & 195.0 (ns) & 9.3 (ns) & $230.0 \mathrm{a}$ & $312.7 \mathrm{a}$ & 28.3 (ns) \\
\hline Second & Immaculate & 10 t/ha PM & $127.0 \mathrm{a}$ & 266.0 (ns) & 0.0 (ns) & $183.3 \mathrm{c}$ & 323.3a & 43.7 (ns) \\
\hline Second & Immaculate & 20 t/ha PM & $35.8 \mathrm{f}$ & 41.5 (ns) & 8.5 (ns) & $79.9 \mathrm{~g}$ & $80.3 \mathrm{f}$ & 34.5 (ns) \\
\hline Second & P.H. Baby & 0 t/ha PM & $55.5 \mathrm{~d}$ & 45.0 (ns) & 0.5 (ns) & 88.0f & $110.3 e$ & 14.0 (ns) \\
\hline Second & P.H. Baby & 5 t/ha PM & $57.2 \mathrm{~d}$ & 104.6 (ns) & 24.3 (ns) & $135.5 d$ & $206.3 c$ & 69.0 (ns) \\
\hline Second & P.H. Baby & 10 t/ha PM & $68.5 c$ & 92.0 (ns) & 16.5 (ns) & 103.3e & $149.7 d$ & 35.0 (ns) \\
\hline Second & P.H. Baby & 20 t/ha PM & $41.5 \mathrm{e}$ & 54.0 (ns) & 6.5 (ns) & $87.0 \mathrm{f}$ & $112.3 \mathrm{e}$ & 26.3 (ns) \\
\hline
\end{tabular}

Means of data within the same column followed by same letters are not significantly different by Fisher’s test, ns $=$ not significant, ${ }^{\dagger}=$ weeks after transplanting.

recorded for year two consistently taller height and more leaves in both experiment I and II and more cumulative number of leaves in experiment II. Thus the plants treated with $10 \mathrm{t} / \mathrm{ha}$ PM in year two were taller with more leaves in experiment I, but plants treated with $5 \mathrm{t} / \mathrm{ha}$ were taller, had more leaves and more flowers in experiment II. Nonetheless, plants treated with $5 \mathrm{t} / \mathrm{ha}$ and $20 \mathrm{t} / \mathrm{ha}$ had taller plants, more leaves and flowers in experiment I and had taller plants in experiment II but all manure rates had more leaves than $0 \mathrm{t} / \mathrm{ha}$ in experiment II (Table 7). For the "Immaculate" compared to the "P.H. Baby", significant taller plants with more leaves in experiment I and II, and more flowers and thicker girth in experiment II were obtained. Although the plants treated with 5 t/ha PM were taller in both experiment I and II, and plants treated with $10 \mathrm{t} / \mathrm{ha} \mathrm{PM}$ had more leaves in 
Table 7. Season $\times$ species interaction effects of rose cultivars in response to seasonal variation and manure application rates at 16 and 40 w.a.t.

\begin{tabular}{|c|c|c|c|c|c|c|c|c|c|}
\hline \multirow[b]{2}{*}{ Season } & \multirow[b]{2}{*}{ Manure rate } & \multicolumn{3}{|c|}{ Experiment one } & \multicolumn{5}{|c|}{ Experiment two } \\
\hline & & $\begin{array}{l}\text { Plant height } \\
\quad(\mathrm{cm})\end{array}$ & $\begin{array}{l}\text { No. of } \\
\text { leaves }\end{array}$ & $\begin{array}{l}\text { Cum. number } \\
\text { of flower } \\
\text { buds }\end{array}$ & $\begin{array}{l}\text { Cum. number } \\
\text { of opened } \\
\text { flowers }\end{array}$ & $\begin{array}{l}\text { Plant height } \\
\text { (cm) }\end{array}$ & $\begin{array}{l}\text { No. of } \\
\text { leaves }\end{array}$ & $\begin{array}{l}\text { Cum. } \\
\text { number of } \\
\text { flower } \\
\text { buds }\end{array}$ & $\begin{array}{l}\text { Cum. } \\
\text { number } \\
\text { of opened } \\
\text { flowers }\end{array}$ \\
\hline & & \multicolumn{3}{|c|}{$16^{\dagger}$} & \multicolumn{5}{|c|}{$40^{\dagger}$} \\
\hline First & 0 t/ha PM & $22.8 \mathrm{~g}$ & 58.3ef & 4.0 (ns) & 1.0 (ns) & 32.3e & $100.0 \mathrm{e}$ & 7.3d & 4.7 (ns) \\
\hline First & 5 t/ha PM & $30.2 \mathrm{e}$ & $82.5 d$ & 10.0 (ns) & 2.0 (ns) & $41.8 \mathrm{~d}$ & $121.0 \mathrm{~d}$ & $8.5 \mathrm{~d}$ & 4.7 (ns) \\
\hline First & 10 t/ha PM & $27.4 \mathrm{f}$ & $69.8 \mathrm{e}$ & 6.2 (ns) & 1.0 (ns) & $35.1 \mathrm{e}$ & $115.7 d$ & $9.8 \mathrm{~d}$ & 4.7 (ns) \\
\hline First & 20 t/ha PM & 28.4ef & $81.5 \mathrm{~d}$ & 10.0 (ns) & 1.5 (ns) & $38.9 d$ & $116.5 d$ & $9.7 d$ & 3.3 (ns) \\
\hline Second & 0 t/ha PM & $90.0 \mathrm{c}$ & $126.3 \mathrm{c}$ & 11.3 (ns) & 5.8 (ns) & $140.5 b$ & $185.0 \mathrm{c}$ & $60.8 d$ & 30.5 (ns) \\
\hline Second & 5 t/ha PM & $93.6 \mathrm{~b}$ & $149.8 b$ & 38.3 (ns) & 16.8 (ns) & $192.2 \mathrm{a}$ & $259.5 \mathrm{a}$ & $193.1 \mathrm{a}$ & 48.7 (ns) \\
\hline Second & 10 t/ha PM & $97.8 \mathrm{a}$ & $179.0 \mathrm{a}$ & 34.3 (ns) & 8.3 (ns) & $143.3 \mathrm{~b}$ & $236.5 b$ & 149.3b & 39.3 (ns) \\
\hline Second & 20 t/ha PM & $38.6 \mathrm{~d}$ & $47.8 \mathrm{f}$ & 15.0 (ns) & 7.5 (ns) & $83.5 c$ & $96.3 e$ & 73.0c & 30.4 (ns) \\
\hline
\end{tabular}

Means of data within the same column followed by same letters are not significantly different by Fisher’s test, ns $=$ not significant, ${ }^{\dagger}=$ weeks after $^{\prime}$ transplanting.

experiment I, and those with both 5 t/ha and 10 t/ha had more leaves in experiment II,. nonetheless the "P.H. Baby" recorded more flowers and thicker girth in experiment I and II respectively, while the plants treated with $5 \mathrm{t} / \mathrm{ha}$ were best in flower formation and in thicker girth compared to the "Immaculate" (Table 8).

\subsection{Correlation Relationship between Season, Specie and Manure}

In experiment I, significant correlation $(\mathrm{p} \leq 0.05)$ responses were obtained in the roses cultivated in dry season (Table 9). Season variation was significantly correlated with plant height but negatively correlated with stem girth. Both species and manure recorded no significant correlation with growth and flowering pattern of roses. Although cumulative number of bud (CNBD) significantly correlated with cumulative number of flowers (CNFL), all vegetative growth parameters were not correlated with flowering, nonetheless plant height was significantly correlated with number of leaves, and slightly but negatively correlated with stem girth.

In experiment II, significant correlation $(\mathrm{p} \leq 0.05)$ responses were obtained in the roses cultivated in the wet season (Table 10). Season was significantly correlated with plant height, cumulative number of bud and cumulative number of flowers, but negatively correlated with stem girth. Both species and manure recorded no significant correlation with growth and flowering pattern of roses. Nonetheless plant height was significantly correlated with number of leaves, cumulative number of bud and cumulative number of flowers but negatively correlated with stem girth. The cumulative number of bud significantly correlated with cumulative number of flowers.

\section{Discussion}

\subsection{Sources of Seasonal Variation}

Although seasonal variation through recorded data over the years could be predicted to a reasonable level, the effect of climate change now a global phenomenon is introducing another dimension in local temperature range which brings serious concerns to species adaptability, survival and/or productivity responses to such observed changes. In this study, seasonal variation (rainfall, temperature, evaporation and sunshine duration) were varied for the period of study which could have accounted for environmental variations that affected the rose cultivars in growth and yield. The variations observed showed a reduced value of year two rainfall in experiment I compared to the relative increase in year two of experiment II, accompanied by greater reduction albeit with greater increase in values of maximum and minimum temperature respectively, alongside the greater reduction in evaporation coupled with greater increase in sunshine duration in experiment II compared to obtainable experiment 
Table 8. Season $\times$ species interaction effects of rose cultivars in response to seasonal variation and manure application rates at 16 and 40 w.a.t.

\begin{tabular}{|c|c|c|c|c|c|c|c|c|c|}
\hline \multirow[b]{2}{*}{ Species } & \multirow[b]{2}{*}{ Manure rate } & \multicolumn{3}{|c|}{ Experiment one } & \multicolumn{5}{|c|}{ Experiment two } \\
\hline & & $\begin{array}{l}\text { Plant height } \\
\text { (cm) }\end{array}$ & $\begin{array}{l}\text { Stem girth } \\
\text { (cm) }\end{array}$ & $\begin{array}{l}\text { Number } \\
\text { of leaves }\end{array}$ & $\begin{array}{l}\text { Cum. number } \\
\text { of opened } \\
\text { flowers }\end{array}$ & $\begin{array}{l}\text { Plant height } \\
\text { (cm) }\end{array}$ & $\begin{array}{l}\text { Stem girth } \\
\quad(\mathrm{cm})\end{array}$ & $\begin{array}{l}\text { Number } \\
\text { of leaves }\end{array}$ & $\begin{array}{l}\text { Cum. number } \\
\text { of opened } \\
\text { flowers }\end{array}$ \\
\hline & & \multicolumn{3}{|c|}{$16^{\dagger}$} & \multicolumn{5}{|c|}{$40^{\dagger}$} \\
\hline Immaculate & 0 t/ha PM & $73.6 \mathrm{~b}$ & 3.2 (ns) & $141.9 b$ & $6.0 \mathrm{c}$ & $113.0 \mathrm{~b}$ & $4.5 \mathrm{~b}$ & $188.7 \mathrm{~b}$ & 25.7 (ns) \\
\hline Immaculate & 5 t/ha PM & $80.0 \mathrm{a}$ & 3.6 (ns) & $127.0 \mathrm{c}$ & 5.2ef & 133.9a & $4.8 \mathrm{~b}$ & 204.3a & 15.3 (ns) \\
\hline Immaculate & 10 t/ha PM & $74.7 \mathrm{~b}$ & 3.1 (ns) & $160.5 a$ & $0.2 \mathrm{~g}$ & $108.4 \mathrm{c}$ & $4.7 b$ & $207.2 \mathrm{a}$ & 24.0 (ns) \\
\hline Immaculate & 20 t/ha PM & $32.7 f$ & 2.4 (ns) & $59.1 \mathrm{~g}$ & 4.8ef & $60.0 \mathrm{f}$ & $3.8 \mathrm{c}$ & $95.2 \mathrm{f}$ & 18.6 (ns) \\
\hline P.H. Baby & 0 t/ha PM & $39.2 \mathrm{e}$ & 3.1 (ns) & $42.7 \mathrm{~h}$ & $0.8 \mathrm{~g}$ & $59.8 \mathrm{f}$ & $4.6 \mathrm{~b}$ & $96.3 \mathrm{f}$ & 9.5 (ns) \\
\hline P.H. Baby & 5 t/ha PM & $43.8 d$ & 4.3 (ns) & 105.3d & $13.7 \mathrm{a}$ & $81.6 \mathrm{~d}$ & $10.9 a$ & $176.2 \mathrm{c}$ & 38.0 (ns) \\
\hline P.H. Baby & 10 t/ha PM & $50.4 \mathrm{c}$ & 3.3 (ns) & 88.3e & $9.1 b$ & $70.1 \mathrm{e}$ & $4.9 \mathrm{~b}$ & $145.0 \mathrm{~d}$ & 20.0 (ns) \\
\hline P.H. Baby & 20 t/ha PM & $34.4 \mathrm{f}$ & 3.0 (ns) & $70.2 \mathrm{f}$ & $4.3 \mathrm{f}$ & $62.5 f$ & $4.6 \mathrm{~b}$ & $117.7 \mathrm{e}$ & 15.2 (ns) \\
\hline
\end{tabular}

Means of data within the same column followed by same letters are not significantly different by Fisher's test, ns $=$ not significant, ${ }^{\dagger}=$ weeks after transplanting.

Table 9. Correlation relationships between season, species and manure rates treatments and the vegetative growth and yield parameters of rose cultivars at 16 w.a.t.

\begin{tabular}{|c|c|c|c|c|c|c|c|c|c|c|}
\hline Parameters & Season & Species & Manure & PHT & SGT & NLV & CNB & CNF & NF/NB & FYD \\
\hline Season & 1.000 & 1.000 & 1.000 & $0.683^{* *}$ & $-0.842^{* *}$ & $0.351^{*}$ & $0.450^{* *}$ & $0.483^{* *}$ & $0.161 \mathrm{~ns}$ & $0.420^{* *}$ \\
\hline Species & & 1.000 & 1.000 & $-0.302^{*}$ & $0.071 \mathrm{~ns}$ & $-0.303^{*}$ & $0.271 \mathrm{~ns}$ & $0.172 \mathrm{~ns}$ & $-0.071 \mathrm{~ns}$ & $0.214 \mathrm{~ns}$ \\
\hline Manure & & & 1.000 & $-0.196 \mathrm{~ns}$ & $-0.102 \mathrm{~ns}$ & $-0.111 \mathrm{~ns}$ & $0.063 \mathrm{~ns}$ & $-0.019 \mathrm{~ns}$ & $-0.117 \mathrm{~ns}$ & $0.112 \mathrm{~ns}$ \\
\hline PHT & & & & 1.000 & $-0.444^{* *}$ & $0.810^{* *}$ & $0.295^{*}$ & $0.277 \mathrm{~ns}$ & $0.173 \mathrm{~ns}$ & $0.162 \mathrm{~ns}$ \\
\hline SGT & & & & & 1.000 & $-0.069 \mathrm{~ns}$ & $-0.245 \mathrm{~ns}$ & $-0.322^{*}$ & $-0.140 \mathrm{~ns}$ & $-0.301^{*}$ \\
\hline NLF & & & & & & 1.000 & $0.321^{*}$ & $0.220 \mathrm{~ns}$ & $0.094 \mathrm{~ns}$ & $0.090 \mathrm{~ns}$ \\
\hline CNB & & & & & & & 1.000 & $0.889^{* *}$ & $0.519^{* *}$ & $0.871^{* *}$ \\
\hline CNF & & & & & & & & 1.000 & $0.506^{* *}$ & $0.893^{* *}$ \\
\hline NF/NB & & & & & & & & & 1.000 & $0.383^{* *}$ \\
\hline FYD & & & & & & & & & & 1.000 \\
\hline
\end{tabular}

${ }^{* *}=$ significant at $0.01,{ }^{*}=$ significant at $0.05, \mathrm{~ns}=$ not significant, $\mathrm{PHT}=$ plant height, $\mathrm{SGT}=$ stem girth, NLV $=$ number of leaves, CNB $=$ cumulative number of flower buds, CNF cumulative number of opened flowers, NF/NB = flowers per flower buds, FYD = flower yield.

Table 10. Correlation relationships between season, species and manure rates treatments and the vegetative growth and yield parameters of rose cultivars at 40 w.a.t.

\begin{tabular}{|c|c|c|c|c|c|c|c|c|c|c|}
\hline Parameters & Season & Species & Manure & PHT & SGT & NLV & CNB & CNF & NF/NB & FYD \\
\hline Season & 1.000 & 1.000 & 1.000 & $0.778^{* *}$ & $-0.673^{* *}$ & $0.453^{* *}$ & $0.698^{* *}$ & $0.645^{* *}$ & $-0.424^{* *}$ & $0.653^{* *}$ \\
\hline Species & & 1.000 & 1.000 & $-0.278 \mathrm{~ns}$ & $0.237 \mathrm{~ns}$ & $-0.224 \mathrm{~ns}$ & $0.029 \mathrm{~ns}$ & $-0.004 \mathrm{~ns}$ & $-0.197 \mathrm{~ns}$ & $0.015 \mathrm{~ns}$ \\
\hline Manure & & & 1.000 & $-0.166 \mathrm{~ns}$ & $-0.125 \mathrm{~ns}$ & $-0.153 \mathrm{~ns}$ & $0.001 \mathrm{~ns}$ & $-0.030 \mathrm{~ns}$ & $-0.155 \mathrm{~ns}$ & $0.097 \mathrm{~ns}$ \\
\hline PHT & & & & 1.000 & $-0.511^{* *}$ & $0.819^{* *}$ & $0.685^{* *}$ & $0.595^{* *}$ & $-.0 .308^{*}$ & $0.545^{* *}$ \\
\hline SGT & & & & & 1.000 & $-0.085 \mathrm{~ns}$ & $-0.236 \mathrm{~ns}$ & $-0.242 \mathrm{~ns}$ & $0.196 \mathrm{~ns}$ & $-0.279 \mathrm{~ns}$ \\
\hline NLF & & & & & & 1.000 & $0.606^{* *}$ & $0.462^{* *}$ & $-0.320^{*}$ & $0.403^{* *}$ \\
\hline CNB & & & & & & & 1.000 & $0.821^{* *}$ & $0.373^{* *}$ & $0.830^{* *}$ \\
\hline CNF & & & & & & & & 1.000 & $0.073 \mathrm{~ns}$ & $0.977^{* *}$ \\
\hline NF/NB & & & & & & & & & 1.000 & $0.096 \mathrm{~ns}$ \\
\hline FYD & & & & & & & & & & 1.000 \\
\hline
\end{tabular}

${ }^{* *}=$ significant at $0.01,{ }^{*}=$ significant at $0.05, \mathrm{~ns}=$ not significant, PHT = plant height, SGT $=$ stem girth, NLV = number of leaves, CNB $=$ cumulative number of flower buds, CNF cumulative number of opened flowers, NF/NB = flowers per flower buds, FYD = flower yield. 
I. Although the observed crop response to temperature did not conform strictly with earlier report by [31] that the daily minimum temperature was probably more important than maximum temperature ${ }^{\circ} \mathrm{C}$ because flowers usually open before midday, but captured another variable in the temperature influence on flower induction. Therefore in the absence of a decrease in minimum temperature, the observed temperature difference between the maximum and minimum temperatures played the major role of induction mechanism in the rose cultivars. Thus the differences between the maximum and minimum temperatures recorded for both years one and two which were higher in experiment II $\left(10.1^{\circ} \mathrm{C}\right.$ and $9.8^{\circ} \mathrm{C}$ respectively) compared to obtainable in experiment I $\left(9.7^{\circ} \mathrm{C}\right.$ and $8.8^{\circ} \mathrm{C}$ respectively) were implicated in the flower induction and production differences in both stages of the study.

\subsection{Seasonal Effect of Environmental Condition on Growth and Yield of Roses}

The seasonal variations in year two of this study caused significant increase in crop growth in both experiment I and II. Thus the significantly higher year two responses in plant height and number of leaves although with corresponding significant decrease in stem girth could be due to higher moisture and lower evaporation. Although drier weather in year two of experiment I coupled with lower maximum temperature could trigger flower bud initiation [32]-[34], but could not sustain number of opened flowers, while the reverse in year two of experiment II could be due to higher evapo-transpiration affecting flower opening. Also despite the higher minimum temperature, the lower maximum temperature and longer sunshine durations could have influenced more cumulative number of flower buds and opened flowers. This indicated the influence of lower temperature in flower induction, which confirms the report by [2] that floral intensity (flowers per shoot) increases with accumulated low temperatures, and diminishes with the presence of crop load and the occurrence of high temperatures, in which the latter may be related to sprouting of flowering buds. Moreover, the corresponding decrease in margin of opened flowers compared to number of flower buds in experiment II compared to obtainable in experiment I indicated that there exists a proportionate supportive threshold required for soil moisture which was not met in experiment II indicating that rain-fed rose cultivation would require supplemental irrigation for effective productivity.

Despite the positive influence of season in experiment I and II resulting in positive correlation with plant height and number of leaves but negative correlation with stem girth, the non-correlation of season on the one hand and of plant growth parameters (plant height and number of leaves) on the other hand with flowering in experiment I compared to the significance correlation with both obtained in experiment II indicated the contribution effect of both on flower formation and revealed influence of environmental factors (of complex interrelationship between rainfall, temperature, evapo-transpiration and irradiation) as the major player in flowering response of roses, while plant height and rate of leaf formation could be regarded as the among the yield determinants in roses. Thus the lower irradiance in reduced sunshine hours of September to December (4.0 and 4.3 hours which gradually increased to 6.3 and 6.2 hours respectively) coupled with reduction in moisture availability (from 181.4 and $136 \mathrm{~mm}$ to 1.3 and $16.5 \mathrm{~mm}$ respectively) accounted for the poor response in Experiment I compared to Experiment II. Also the variability in rainfall pattern and the effect of cloudiness on irradiance affecting quality of light during raining season in experiment II between March and June in 2013 and 2014 accounted for the depression observed in flowering pattern, while the reduced temperature triggered a later improvement in flowering pattern. This confirmed the report of [35] that despite the role water stress can play, drought conditions is not as beneficial for flowering as cool weather.

Moreover, the differences in absorptance capacities of both cultivars could have accounted for the different flowering behaviours displayed in experiment I and II where the "P.H. Baby" was more prolific with increasing margin in flowering behaviour in experiment I but the "Immaculate" was triggered to produce more flowers in experiment II thereby reducing the margin of differences between both cultivars to a level of no significant difference. Earlier reports have stated that light quality affects morphogenesis and overall appearance of rose plants, where an increased red/far red ratio in roses reduced plant height and increased leaf chlorophyll content [36] and the number of flowers [37] [38]. In addition several plant species including roses which have leaves with different visual appearance [39]-[41], have red leaves containing higher concentration of anthocyanins which showed slightly higher absorptance of green light compared to the green leaves, hence the differences in absorptance of green light were attributed to the contribution of varying levels of anthocyanins in such leaves [42] [43]. The variation in red leaves component over time during leaf flush of the two cultivars could have contributed to both 
the appearance and flowering behaviours of both in this study.

\subsection{Species Effect of Rose Cultivars on Growth and Yield of Roses}

The "Immaculate" however, appeared more vigorous compared to "P.H. Baby" in the taller height and more leaf production. The year two condition favoured both cultivars in plant height and number of leaves compared to year one, although "P.H. Baby" thrived better in year one than "Immaculate". The better stem girth development in "P.H. Baby" probably supported the prolific flowering habit in experiment II. Nonetheless, the non-correlation between plant species type and vegetative growth or flowering pattern of roses indicated that other factors apart from both plant species type and manure rate were involved in the responses obtained in rose cultivation as earlier stated above. The no significant difference in CNB, CNF and FYD among both cultivars in experiment II could mean that better environmental condition compared to obtainable in experiment I accounted for in the wider margin in temperature differences between max. and min. temp., higher evapo-transpiration and longer sunshine duration could have favoured both cultivars and triggered CNB and CNF in the "Immaculate" in particular to a level of no dominance among both cultivars.

\subsection{Manure Effect on Growth and Yield of Roses}

The manure effect expressed itself in plant height, stem girth, number of leaves and cumulative number of flower buds but could not sustain cumulative number of opened flowers. The non-correlation between manure rate and vegetative growth or flowering of roses reveal the poor nutrient availability due to slow rate of mineralization and the high nutrient demanding nature of rose plant, hence the sole dependence on inherent soil fertility. However, both $5 \mathrm{t} / \mathrm{ha}>10 \mathrm{t} / \mathrm{ha} \mathrm{PM}$ in that order had significant influence on vegetative growth compared to those treated with $20 \mathrm{t} / \mathrm{ha}$. Also [18]-[20] had reported that $\mathrm{N}$ mineralization increased with increasing moisture content and temperature and hence $\mathrm{N}$ mineralization will be greatest during warmer periods when soils are moist [21] nonetheless the net release of nutrients from organic matter is a function of decomposition ratios of the different organic matter fractions and of the uptake of nutrients by the growing biomass [44]. Hence the bulkier nature of the $20 \mathrm{t}$ /ha will require more moisture and temperature input before meaningful decomposition processes compared to lower rates.

The "Immaculate" and "P.H. Baby" kept their identity in response to the level of available nutrient in the soil. The higher "Immaculate" plants ability to thrive in unfertilized plots with $0 \mathrm{t} / \mathrm{ha}$ could be due to the inherent ability to thrive in any soil while the "P.H. Baby" is nutrient demanding and will require more nutrient availability before any meaningful performance. Nonetheless, the plants treated with $20 \mathrm{t} / \mathrm{ha}$ could not perform favourably compared to other lower rates due to the much bulkier nature thus requiring more input of natural resources to mineralize leading to poor nutrient uptake by plants. The plants treated with unfertilized $0 \mathrm{t} / \mathrm{ha}$ were least in growth responses indicating that rose plants were high nutrient demanding plants. Hence, except under practical organic farming, addition of inorganic fertilizers may be required to sustain increased flower yield [45]-[47]. Moreover, the more CNF in plant treated with $5 \mathrm{t} / \mathrm{ha}$ PM compared to other rates but no significant different in FYD among all manure rates indicated a compensatory effect from higher floral unit weight of plants treated with $10 \mathrm{t} / \mathrm{ha}$ or $20 \mathrm{t} / \mathrm{ha} \mathrm{PM}$ rates, which is a measure of the better flower quality produced at higher manure rates. Nonetheless [48] had earlier reported that higher floral unit weight induced by higher nutrient uptake is inversely proportional to vase life quality and length of days of cut-flowers in storage.

The synergy between seasonal conditions expressed in year two and manure rates produced better growth in both cultivars compared to obtainable in year one of both experiment I and II, and in better CNB in experiment II. The better plant growth when treated with $10 \mathrm{t} / \mathrm{ha}$ in experiment I could be due to the relative higher micro-nutrient content released compared to obtainable in those treated with $5 \mathrm{t} /$ ha while the better performance of plants treated with $5 \mathrm{t} / \mathrm{ha}$ in experiment II could be due to poor mineralization and nutrient exhaustion in the 10 t/ha. However, 5 t/ha appeared optimum for both year one and two seasons in experiment I and II, although the more leaves of plants treated with 0 t/ha could be due to inherent soil fertility and the poor rate of mineralization.

\subsection{Conclusion}

In conclusion, in the absence of the required decrease in minimum temperature, although level of moisture 
availability and light quality were also implicated, the margin of temperature difference between the maximum and minimum temperatures played the major role of flower buds induction mechanism in the rose cultivars. The "Immaculate" and "P.H. Baby" kept their identity in response to level of available nutrient in the soil. The higher "Immaculate" plants' responses and ability to thrive in unfertilized plots with 0 t/ha compared to the "P.H. Baby" further revealed the genetic differences. The "P.H. Baby" appeared to be more nutrient demanding due to the prolific ability in flower production compared to the more vigorous "Immaculate". The $5 \mathrm{t} / \mathrm{ha}$ manure application rate was more optimum for both years one (dry) and two (wet) seasons' production of roses in both the vegetative growth and flower production. Although the more number of leaves produced by plants treated with 0 $\mathrm{t} / \mathrm{ha}$ could be due to inherent soil fertility and the poor rate of mineralization in the applied manure.

\section{References}

[1] Australian Govt. (2005) The Biology and Ecology of Rosa $\times$ Hybrid (Rose). Department of Health and Ageing, Office of the Gene Technology Regulator, Australia, 1-18.

[2] Albrigo, L.G. and Sauco, V.G. (2004) Flower Bud Induction, Flowering and Fruit-Set of Some Subtropical and Subtropical Fruit Tree Crops with Special Reference to Citrus. In: Albrigo, L.G. and Sauco, V.G., Eds., Proceedings of the XXVI IHC-Citrus, Subtropical and Tropical Fruit Crops, Acta Horticulturae, 632, 81-90.

[3] Särkkä, L. (2004) Yield, Quality and Vase Life of Cut Roses in Year-Round Greenhouse Production. Academic Dissertation, Department of Applied, University of Hlsinki, Publication No. 23, 64 p.

[4] Davenport, T.L. (1990) Citrus Flowering. Horticultural Reviews, 12, 349-408.

[5] Hamrick, J.L. (2004) Response of Forest Trees to Global Environmental Changes. Forest Ecology and Management, 197, 323-335. http://dx.doi.org/10.1016/j.foreco.2004.05.023

[6] Botkin, D.B., Saxe, H., Araújo, M.B., Betts, R., Bradshaw, R.H.W., Cedhagen, T., Chesson, P., Dawson, T.P., Etterson, J.R., Faith, D.P., Ferier, S., Guisan, A., Skjoldborg Hansen, A., Hilbert, D.W., Loehle, C., Margules, C., New, M., Sobel, M.J. and Stockwell, D.R.B. (2007) Forecasting the Effects of Global Warming on Biodiversity. BioScience, 57, 227-236. http://dx.doi.org/10.1641/B570306

[7] Kremer, A. (2007) How Well Can Existing Forests Withstand Climate Change? In: Koskela, J., Buck, A., Teissier du Cros, E. Eds., Climate Change and Forest Genetic Diversity: Implications for Sustainable Forest Management in Europe, Bioversity International, Rome, 3-17.

[8] Khangoli, S. (2001) Potential of Growth Regulators on Control of Size and Flowering of Ornamental Plants. Proceeding of First Applied Scientific Seminar on Flowering and Ornamental Plants, Mahallat.

[9] Gudin, S. (2000) Rose: Genetics \& Breeding. In: Janick, J. Ed., Plant Breeding Reviews, Vol. 17, John Wiley \& Son, Inc., 159-189.

[10] Goss, M.J., Beauchamp, E.G. and Miller, M.H. (1995) Can a Farming Systems Approach Help Minimize Nitrogen Losses to the Environment? Journal of Contaminant Hydrology, 20, 285-297. http://dx.doi.org/10.1016/0169-7722(95)00074-7

[11] Allen, S.C., Nair, V.D., Graetz, D.A., Jose, S. and Nair, P.K.R. (2006) Phosphorus Loss from Organic versus Inorganic Fertilizers Used in Alley Cropping on a Florida Ultisol. Agriculture, Ecosystems \& Environment, 117, 290-298. http://dx.doi.org/10.1016/j.agee.2006.04.010

[12] Stevens, R.J., Laughlin, R.J. and Frost, J.P. (1992) Effects of Separation, Dilution, Washing and Acidification on Ammonium Volatilization from Surface Applied Cattle Slurry. Journal of Agricultural Science (Cambridge), 119, 383-389. http://dx.doi.org/10.1017/S0021859600012223

[13] Stevens, R.J., Laughlin, R.J., Frost, J.P. and Anderson, R. (1992) Evaluation of Separation Plus Acidification with Nitric Acid and Separation Plus Dilution to Make Cattle Slurry a Balanced, Efficient Fertilizer for Grass and Silage. Journal of Agricultural Science (Cambridge), 119, 391-399. http://dx.doi.org/10.1017/S0021859600012235

[14] Yang, C.M., Yang, L.Z., Yang, Y.X. and Ouyang, Z. (2004) Rice Root Growth and Nutrient Uptake as Influenced by Organic Manure in Continuously and Alternately Flooded Paddy Soils. Agricultural Water Management, 70, 67-81. http://dx.doi.org/10.1016/j.agwat.2004.05.003

[15] Badgley, C., Moghtader, J., Quintero, E., Zakem, E., Chappell, M.J., Avilés-Vázquez, K., Samulon, A. and Perfecto, I. (2007) Organic Agriculture and the Global Food Supply. Renewable Agriculture and Food Systems, 22, 86-108. http://dx.doi.org/10.1017/S1742170507001640

[16] Pretty, J.N., Morison, J.I.L. and Hine, R.E. (2003) Reducing Food Poverty by Increasing Agricultural Sustainability in Developing Countries. Agriculture, Ecosystems \& Environment, 95, 217-234.

http://dx.doi.org/10.1016/S0167-8809(02)00087-7 
[17] Uphoff, N. (2003) Higher Yields with Fewer External Inputs? The System of Rice Intensification and Potential Contributions to Agricultural Sustainability. International Journal of Agricultural Sustainability, 1, 38-50. http://dx.doi.org/10.3763/ijas.2003.0105

[18] Addiscott, T.M. (1983) Kinetics and Temperature Relationships of Mineralization and Nitrification in Rothamsted Soils with Differing Histories. European Journal of Soil Science, 34, 343-353.

[19] Broadbent, F.E. (1986) Effects of Organic Matter on Nitrogen and Phosphorus Supply to Plants. In: Chen, Y. and Avnimelech, Y., Eds., The Role of Organic Matter in Modern Agriculture, Martinus Nijhoff Publishers, Dordrecht, 13-27.

[20] Kanal, A. (1995) Effect of Incorporation Depth and Soil Climate on Straw Decomposition Rate in a Loamy Podzoluvisol. Biology and Fertility of Soils, 20, 190-196. http://dx.doi.org/10.1007/BF00336557

[21] Mitchell, R.D.J., Harrison, R., Russell, K.J. and Wess, J. (2000) The Effect of Crop Residue Incorporation Date on Soil Inorganic Nitrogen, Nitrate Leaching and Nitrogen Mineralization. Biology and Fertility of Soils, 32, 294-301. http://dx.doi.org/10.1007/s003740000251

[22] Brandt, K. and Molgaard, P. (2001) Organic Agriculture: Does It Enhance or Reduce the Nutritional Value of Plant Foods? Journal of the Science of Food and Agriculture, 81, 924-931. http://dx.doi.org/10.1002/jsfa.903

[23] USDA-NOP (2009) United States Department of Agriculture. National Organic Program. http://www.ams.usda.gov/AMSv1.0/NOP

[24] Vandermeer, J., Lawrence, D., Symstad, A. and Hobbie, S. (2002) Effects of Biodiversity on Ecosystem Functioning in Managed Ecosystems. In: Loreau, M., Naeem, S. and Inchausti, P., Eds., Biodiversity and Ecosystem Functioning: Synthesis and Perspectives, Oxford University Press, Oxford, 157-168.

[25] Kremen, C. (2005) Managing Ecosystem Services: What Do We Need to Know about Their Ecology? Ecology Letters, 8, 468-479. http://dx.doi.org/10.1111/j.1461-0248.2005.00751.x

[26] Jackson, L.E., Pascual, U. and Hodgkin, T. (2007) Utilizing and Conserving Agrobiodiversity in Agricultural Landscapes. Agriculture, Ecosystems \& Environment, 121, 196-210. http://dx.doi.org/10.1016/j.agee.2006.12.017

[27] Sobulo, R.H. and Osiname, O.A. (1981) Soil Fertilization Use in Western Nigerian. AR \& T Research Bulletin No. 11, 3-6.

[28] Lowell, J.F. (1998) Producing Foods without Pesticides: Local Solutions to Crop Pest Control in West Africa. Technical Center for Agricultural and Rural Cooperation, Wageningen.

[29] SAS (1990) Statistical Analysis System SA/STAT Users' Guide. Version 6, Fourth Edition, SAS Institute, Cary.

[30] Gomez, K.A. and Gomez, A.A. (1984) Statistical Procedures for Agricultural Research. 2nd Edition, an International Rice Research Institute Book, Wiley-Interscience Publication, John Wiley \& Sons, New York.

[31] Olasantan, F.O. (2003) Effects of Season and Cassava/Okra Intercropping on Okra Production in South Western Nigeria. Nigerian Journal of Horticultural Science, 8, 88-94.

[32] Schaffer, B., Whiley, A.W. and Crane, J.H. (1994) Mango. In: Schaffer, B. and Andersen, P.C., Eds., Handbook of Environmental Physiology of Fruit Crops, Vol. II: Subtropical and Tropical Crops, CRC Press, Boca Raton, 165-197.

[33] Whiley, A.W. and Schaffer, B. (1997) Stress Physiology, Chapter V. In: Litz, R.E., Ed., The Mango, Botany, Production and Uses, CAB International, Wallingford, 147-176.

[34] Bally, I.S.E., Harris, M. and Whiley, A.W. (2000) Effect of Water Stress on Flowering and Yield of "Kensington Pride" Mango (Mangifera indica L.). Acta Horticulturae, 509, 277-281.

[35] Menzel, C. (2001) The Physiology of Growth and Cropping in Litvhi. Acta Horticulturae, 558, 175-184.

[36] McMahon, M.J. and Kelly, J.W. (1990) Influence of Spectral Filters on Height, Leaf Chlorophyll and Flowering of Rosa x hybrida "Meirutral”. Journal of Environmental Horticulture, 8, 209-211.

[37] Roberts, G.L., Tsujita, M.J. and Dansereau, B. (1993) Supplemental Light Quality Affects Bud-Break, Yield and Vase Life of Cut Roses. HortScience, 28, 621-622.

[38] Girault, T., Bergougnoux, V., Combes, D., Viemont, J.D. and Leduc, N. (2008) Light Controls Shoot Meristem Organogenic Activity and Leaf Primordia Growth during Bud Burst in Rosa sp. Plant, Cell \& Environment, 31, 1534-1544. http://dx.doi.org/10.1111/j.1365-3040.2008.01856.x

[39] Burger, J. and Edwards, G.E. (1996) Photosynthetic Efficiency, and Photodamage by UV and Visible Radiation, in Red versus Green Leaf Coleus Varieties. Plant and Cell Physiology, 37, 395-399. http://dx.doi.org/10.1093/oxfordjournals.pcp.a028959

[40] Woodall, G.S., Dodd, I.C. and Stewart, G.R. (1998) Contrasting Leaf Development within the Genus Syzygium. Journal of Experimental Botany, 49, 79-87.

[41] Neill, S. and Gould, K.S. (1999) Optical Properties of Leaves in Relation to Anthocyanin Concentration and Distribution. Canadian Journal of Botany, 77, 1777-1782. http://dx.doi.org/10.1139/cjb-77-12-1777 
[42] Gould, K.S., Kuhn, D.N., Lee, D.W. and Oberbauer, S.F. (1995) Why Leaves Are Sometimes Red. Nature, 378, 241242. http://dx.doi.org/10.1038/378241b0

[43] Smillie, R.M. and Hetherington, S.E. (1999) Photoabatement by Anthocyanin Shields Photosynthetic Systems from Light Stress. Photosynthetica, 36, 451-463. http://dx.doi.org/10.1023/A:1007084321859

[44] Avnimelech, Y. (1986) Organic Residues in Modern Agriculture. In: Chen, Y. and Avnimelech, Y., Eds., The Role of Organic Matter in Modern Agriculture, Martinus Nijhoff Publishers, Dordrecht, 1-10.

[45] Alasiri, K.O., Olaniyan, F.O. and Salami, A. (1998) Growth and Yield of Plantain as Influenced by the Application of Organic and Mineral Fertilizer. Proceedings of the 17th Annual Conference of Horticultural Society of Nigeria, FUNAAB, Abeokuta, 7-10 September 1998, 107-111.

[46] Thind, S.S., Sidhu, A.S., Sekhon, N.K. and Hira, G.S. (2004) Integrated Nutrient Management for Sustainable Crop Production in Potato-Sunflower Sequence. Journal of Sustainable Agriculture, 29, 173-188. http://dx.doi.org/10.1300/J064v29n04_12

[47] Sihag, D., Singh, J.P., Mehla, D.S. and Bhardwaj, K.K. (2005) Effect of Integrated Use of Inorganic Fertilizers and Organic Materials on the Distribution of Different Forms of Nitrogen and Phosphorus in Soil. Journal of the Indian Society of Soil Science, 53, 80-84.

[48] Olubode, O.O., Akintokun, A.K., Olosunde, O.M. and Lawal, O.I. (2011) Growth, Yield and Quality Responses of Hybrid Tea Rose Cut-Flowers to Organo-Mineral Fertilizers Rates and Organic Preservatives Using Plant Extracts and Bio-Regulators. Proceedings of 29th Annual National Conference of Horticultural Society of Nigeria (HORTSON), University of Agriculture, Makurdi, 24-29 July 2011, 289-292. 
Scientific Research Publishing (SCIRP) is one of the largest Open Access journal publishers. It is currently publishing more than 200 open access, online, peer-reviewed journals covering a wide range of academic disciplines. SCIRP serves the worldwide academic communities and contributes to the progress and application of science with its publication.

Other selected journals from SCIRP are listed as below. Submit your manuscript to us via either submit@scirp.org or Online Submission Portal.
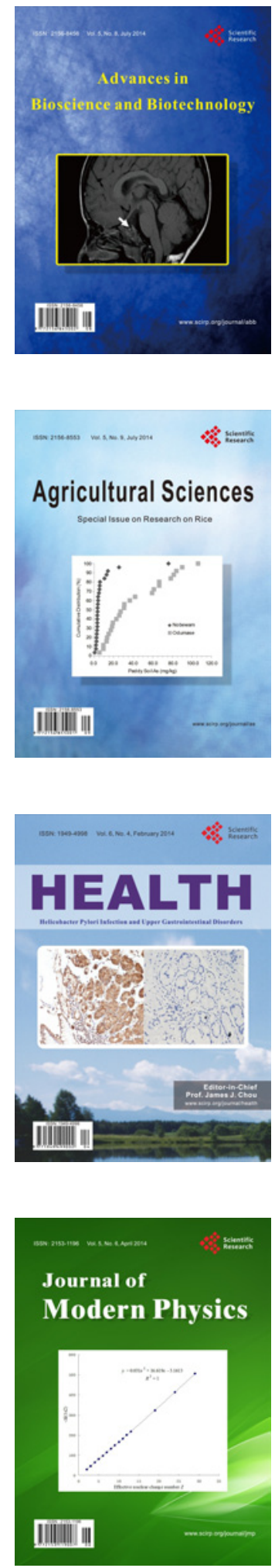
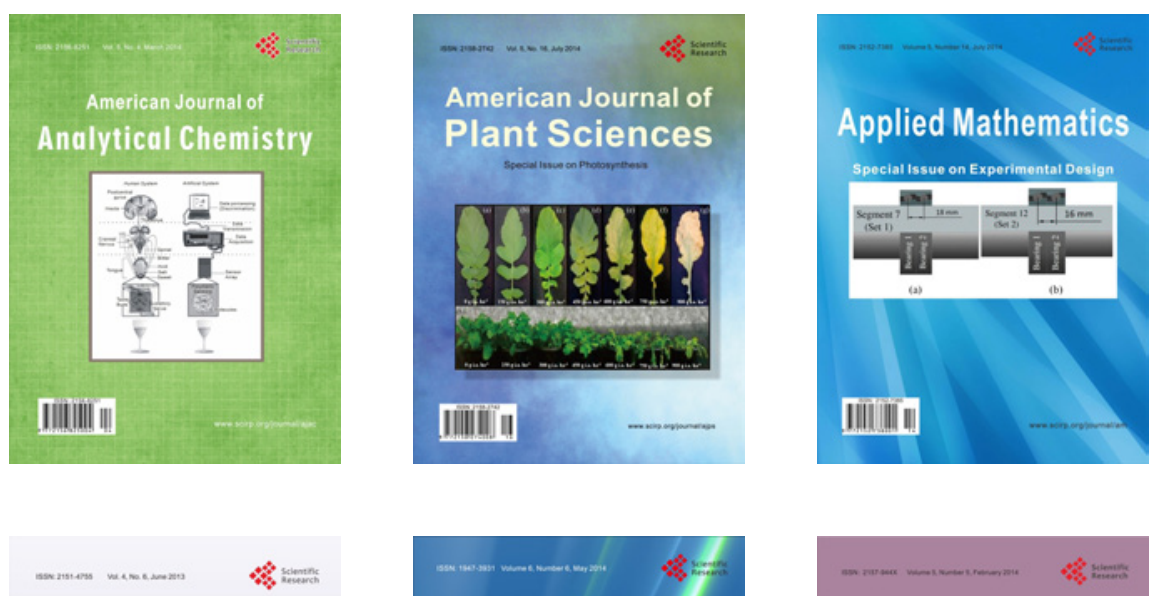

Creative Education
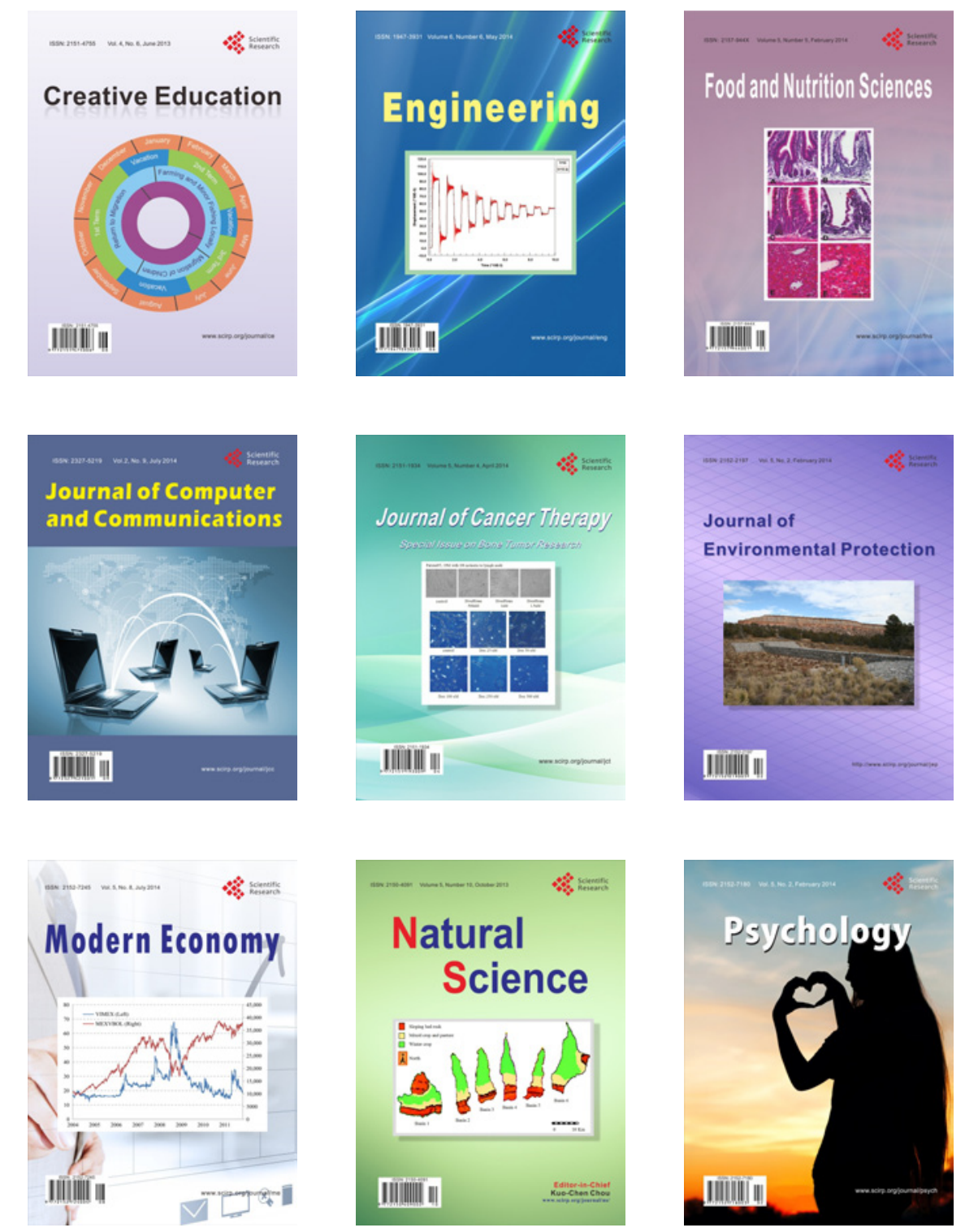